\title{
Crown Ethers and their Alkali Metal Ion Complexes as Assembler Groups in Uranyl-Organic Coordination Polymers with cis-1,3-, cis-1,2- and trans-1,2-Cyclohexanedicarboxylates
}

\author{
Pierre Thuéry* ${ }^{* \dagger}$ Youssef Atoini ${ }^{\ddagger}$ and Jack Harrowfield*,‡
}

${ }^{\dagger}$ NIMBE, CEA, CNRS, Université Paris-Saclay, CEA Saclay, 91191 Gif-sur-Yvette, France FISIS, Université de Strasbourg, 8 allée Gaspard Monge, 67083 Strasbourg, France

\begin{abstract}
Alkali metal cations $\left(\mathrm{Na}^{+}, \mathrm{K}^{+}\right)$and crown ether molecules $(12 \mathrm{C} 4,15 \mathrm{C} 5,18 \mathrm{C} 6)$ were used as additional reactants during the hydrothermal synthesis of uranyl ion complexes with cis/trans-1,3-, cis-1,2- and trans-1,2cyclohexanedicarboxylic acids $\left(c / t-1,3-\mathrm{chdcH}_{2}, c-1,2-\mathrm{chdcH}_{2}\right.$ and $t-1,2-\mathrm{chdcH}_{2}$, respectively, the latter as racemic or pure $(1 R, 2 R)$ enantiomer). Oxalate anions generated in situ are present in all the six complexes isolated and crystallographically characterized, $\left[\left(\mathrm{UO}_{2}\right)_{2}(c-1,3-\mathrm{chdc})_{2}\left(\mathrm{C}_{2} \mathrm{O}_{4}\right)\right]\left[\mathrm{UO}_{2}\left(\mathrm{H}_{2} \mathrm{O}\right)_{5}\right] \cdot(12 \mathrm{C} 4) \cdot 2 \mathrm{H}_{2} \mathrm{O}(\mathbf{1}), \quad\left[\left(\mathrm{UO}_{2}\right)_{4} \mathrm{Na}_{2}(c-1,2-\right.$ chdc $\left.)_{2}\left(\mathrm{C}_{2} \mathrm{O}_{4}\right)_{3}(15 \mathrm{C} 5)_{2}\right] \quad(2), \quad\left[\left(\mathrm{UO}_{2}\right)_{4} \mathrm{~K}_{2}(c-1,2-\mathrm{chdc})_{2}\left(\mathrm{C}_{2} \mathrm{O}_{4}\right)_{3}(18 \mathrm{C} 6)_{1.5}\left(\mathrm{H}_{2} \mathrm{O}\right)_{1.5}\right] \quad(3), \quad\left[\left(\mathrm{UO}_{2}\right)_{12} \mathrm{~K}_{5}(R-t-1,2-\right.$ chdc $\left.)_{4}\left(\mathrm{C}_{2} \mathrm{O}_{4}\right)_{10}(18 \mathrm{C} 6)_{5}(\mathrm{OH})\left(\mathrm{H}_{2} \mathrm{O}\right)_{3}\right] \cdot 4 \mathrm{H}_{2} \mathrm{O}(4),\left[\left(\mathrm{UO}_{2}\right)_{12} \mathrm{~K}_{5}(\mathrm{rac}-\mathrm{t}-1,2-\mathrm{chdc})_{4}\left(\mathrm{C}_{2} \mathrm{O}_{4}\right)_{10}(18 \mathrm{C} 6)_{5}(\mathrm{OH})\left(\mathrm{H}_{2} \mathrm{O}\right)_{3}\right] \cdot 4 \mathrm{H}_{2} \mathrm{O} \quad(5)$, and $\left[\left(\mathrm{UO}_{2}\right)_{8} \mathrm{~K}_{4}(r a c-t-1,2-\mathrm{chdc})_{4}\left(\mathrm{C}_{2} \mathrm{O}_{4}\right)_{6}(18 \mathrm{C} 6)_{3}\left(\mathrm{H}_{2} \mathrm{O}\right)_{2}\right](\mathbf{6})$. In complex $\mathbf{1}$, the $\left[\mathrm{UO}_{2}\left(\mathrm{H}_{2} \mathrm{O}\right)_{5}\right]^{2+}$ counterions link the ladderlike uranyl-containing one-dimensional polymers and the uncomplexed crown ether molecules through hydrogen bonds. In all the other complexes, two-dimensional uranyl/chdc/oxalate subunits are formed, with topologies depending on the stoichiometry, in which the 1,2-chdc ${ }^{2-}$ ligands are bound to three uranium atoms, one of them chelated by the two carboxylate groups, and the oxalate ligands are bis-chelating. In complex 2 , the $\mathrm{Na}(15 \mathrm{C} 5)^{+}$cations are bound to one layer through double $\mathrm{Na}$-carboxylate or $\mathrm{Na}-$ oxo cis-bonding and they are thus mere decorating groups. In contrast, the quasi-planar $\mathrm{K}(18 \mathrm{C} 6)^{+}$groups in 3-6, partially affected by disorder, are generally transcoordinated to two uranyl oxo groups pertaining to different layers, thus uniting the latter into a three-dimensional framework.
\end{abstract}




\section{INTRODUCTION}

The inclusion of a second cation within the lattice of crystalline uranyl ion complexes has proven to be not only a method of increasing the dimensionality of coordination polymers that may be formed but also a means of isolating various uranyl ion clusters and cages. ${ }^{1-5}$ The cations exploited in this way have been drawn from most possible types and include non-metal species such as protonated polypyridines, (alkyl)ammonium ions and phosphonium ions, as well as metal ions in various forms depending upon coligands that they may carry. For alkali metal cations, prediction of the ways in which they might influence a uranyl ion/ligand array is rendered particularly difficult by their variable coordination numbers and flexible coordination geometry. ${ }^{6}$ One means of reducing this difficulty is that of attaching a coligand which leaves a limited number of coordination sites available, preferably also with these sites in a particular relative orientation. One ligand group which provides these capabilities for the alkali metal ions is that of the crown ethers, ${ }^{7}$ in that with the appropriate choice of ring size for the given metal ion, these can provide an essentially planar garland with divergently directed further coordination sites suited to a limited number of possible bridging modes of the metal ion.$^{8-10}$ Examination of the crystal structures reported in the Cambridge Structural Database (CSD, Version 5.38) ${ }^{11}$ shows that crown ethers such as 12-crown-4 (12C4), 15-crown-5 (15C5), 18-crown-6 (18C6) and some of their derivatives have indeed proved useful in the construction of uranyl ion coordination polymers, ${ }^{12-21}$ most often in their uncomplexed state, with only some cases involving a complexed alkali metal cation, either $\mathrm{Na}^{+}$or $\mathrm{K}^{+} .{ }^{16,17,19,21}$ Most of these coordination polymers are based on inorganic ligands such as sulfates, selenates, chromates or phosphates, and only one case with a carboxylate ligand, 1,3cyclohexanedicarboxylate, is known. ${ }^{15}$ The latter complex is a ladder-like one-dimensional (1D) uranyl-containing polymer with hydrogen bonded $15 \mathrm{C} 5$ molecules, which is different from the 
two-dimensional (2D) complex obtained in the absence of a templating species. Following previous work on uranyl complexes with trans-1,2-, cis- and trans-1,4-cyclohexanedicarboxylates, synthesized under solvo-hydrothermal conditions in the presence of various additional cations, ${ }^{22-}$ 24 we have synthesized a series of complexes with cis-1,3-, cis-1,2- and trans-1,2cyclohexanedicarboxylates including crown ether molecules, the latter bound to an alkali metal cation in all cases but one, which have been characterized by their crystal structure and, when possible, their emission spectrum in the solid state. As well as providing novel examples of uranyl coordination polymers with organic ligands involving alkali metal ion complexes of crown ethers, these results also point to a complication in the use of these ethers under hydrothermal conditions, namely the generalized formation of oxalate anions.

\section{EXPERIMENTAL SECTION}

Syntheses. Caution! Uranium is a radioactive and chemically toxic element, and uraniumcontaining samples must be handled with suitable care and protection.

$\mathrm{UO}_{2}\left(\mathrm{NO}_{3}\right)_{2} \cdot 6 \mathrm{H}_{2} \mathrm{O}$ (depleted uranium, R. P. Normapur, 99\%), $\mathrm{NaNO}_{3}$ and $\mathrm{KNO}_{3}$ were purchased from Prolabo, 1,3-cyclohexanedicarboxylic acid (1,3-chdcH $\mathrm{H}_{2}$, mixture of cis and trans isomers) was from Aldrich, cis-1,2-cyclohexanedicarboxylic acid $\left(c-1,2-\mathrm{chdcH}_{2}\right)$ was from Alfa Aesar, rac-trans-1,2-cyclohexanedicarboxylic acid ( $\left.r a c-t-1,2-\mathrm{chdcH}_{2}\right)$ was from Lancaster, 12crown-4 (12C4) and 15-crown-5 (15C5) were from Fluka, and 18-crown-6 (18C6) was from Merck. The $(1 R, 2 R)$ enantiomer of $t-1,2-\mathrm{chdcH}_{2}$, denoted $R-t-1,2-\mathrm{chdcH}_{2}$, was isolated through crystallization with $(R)$-1-phenylethylamine as a resolving agent, as in the literature, ${ }^{25}$ although both the $(1 R, 2 R)$ and $(1 S, 2 S)$ enantiomers are also available commercially. Elemental analyses were performed by MEDAC Ltd. at Chobham, UK. For all syntheses, the mixtures in demineralized 
water were placed in $10 \mathrm{~mL}$ tightly closed glass vessels and heated at $140{ }^{\circ} \mathrm{C}$ under autogenous pressure.

$\left[\left(\mathrm{UO}_{2}\right)_{2}(\mathrm{c}-1,3-\mathrm{chdc})_{2}\left(\mathrm{C}_{2} \mathrm{O}_{4}\right)\right]\left[\mathrm{UO}_{2}\left(\mathrm{H}_{2} \mathrm{O}\right)_{5}\right] \cdot(12 \mathrm{C} 4) \cdot 2 \mathrm{H}_{2} \mathrm{O}$ (1). 1,3-chdcH $2(17 \mathrm{mg}, 0.10 \mathrm{mmol})$, $\mathrm{UO}_{2}\left(\mathrm{NO}_{3}\right)_{2} \cdot 6 \mathrm{H}_{2} \mathrm{O}(35 \mathrm{mg}, 0.07 \mathrm{mmol}), \mathrm{LiNO}_{3}(7 \mathrm{mg}, 0.10 \mathrm{mmol})$, and $12 \mathrm{C} 4(36 \mathrm{mg}, 0.20 \mathrm{mmol})$ were dissolved in water $(0.6 \mathrm{~mL})$. Yellow crystals of complex 1 were obtained within two months (15 mg, 42\% yield based on U). Anal. Calcd for $\mathrm{C}_{26} \mathrm{H}_{50} \mathrm{O}_{29} \mathrm{U}_{3}: \mathrm{C}, 20.27 ; \mathrm{H}, 3.27$. Found: $\mathrm{C}, 20.66$; $\mathrm{H}, 3.30 \%$.

$\left[\left(\cup_{2}\right)_{4} \mathrm{Na}_{2}(c-1,2-c h d c)_{2}\left(C_{2} \mathrm{O}_{4}\right)_{3}(15 \mathrm{C} 5)_{2}\right] \quad$ (2). $\quad c-1,2-\mathrm{chdcH}_{2} \quad(17 \quad \mathrm{mg}, \quad 0.10 \mathrm{mmol})$, $\mathrm{UO}_{2}\left(\mathrm{NO}_{3}\right)_{2} \cdot 6 \mathrm{H}_{2} \mathrm{O}(35 \mathrm{mg}, 0.07 \mathrm{mmol}), \mathrm{NaNO}_{3}(9 \mathrm{mg}, 0.11 \mathrm{mmol})$, and $15 \mathrm{C} 5(22 \mathrm{mg}, 0.10 \mathrm{mmol})$ were dissolved in water $(0.6 \mathrm{~mL})$. Yellow crystals of complex 2 were obtained within two months (14 mg, 37\% yield based on U). Anal. Calcd for $\mathrm{C}_{42} \mathrm{H}_{60} \mathrm{Na}_{2} \mathrm{O}_{38} \mathrm{U}_{4}: \mathrm{C}, 23.24 ; \mathrm{H}, 2.79$. Found: C, 23.50; H, $2.77 \%$.

$\left[\left(\mathrm{UO}_{2}\right)_{4} K_{2}(c-1,2-c h d c)_{2}\left(\mathrm{C}_{2} \mathrm{O}_{4}\right)_{3}(18 \mathrm{C} 6)_{1.5}\left(\mathrm{H}_{2} \mathrm{O}\right)_{1.5}\right] \quad$ (3). $c-1,2-\mathrm{chdcH}_{2}(17 \mathrm{mg}, 0.10 \mathrm{mmol})$, $\mathrm{UO}_{2}\left(\mathrm{NO}_{3}\right)_{2} \cdot 6 \mathrm{H}_{2} \mathrm{O}(35 \mathrm{mg}, 0.07 \mathrm{mmol}), \mathrm{KNO}_{3}(10 \mathrm{mg}, 0.10 \mathrm{mmol})$, and $18 \mathrm{C} 6(26 \mathrm{mg}, 0.10 \mathrm{mmol})$ were dissolved in water $(0.6 \mathrm{~mL})$. Yellow crystals of complex 3 were obtained within one month (16 mg, 42\% yield based on U). Anal. Calcd for $\mathrm{C}_{40} \mathrm{H}_{59} \mathrm{~K}_{2} \mathrm{O}_{38.5} \mathrm{U}_{4}: \mathrm{C}, 21.98 ; \mathrm{H}, 2.72$. Found: $\mathrm{C}$, $22.43 ; \mathrm{H}, 2.78 \%$.

$\left[\left(\mathrm{UO}_{2}\right)_{12} \mathrm{~K}_{5}(\mathrm{R}-\mathrm{t}-1,2-\mathrm{chdc})_{4}\left(\mathrm{C}_{2} \mathrm{O}_{4}\right)_{10} \mathrm{O}(18 \mathrm{C} 6)_{5}(\mathrm{OH})\left(\mathrm{H}_{2} \mathrm{O}\right)_{3}\right] \cdot 4 \mathrm{H}_{2} \mathrm{O}$ (4). $R-t-1,2-\mathrm{chdcH}_{2}(17 \mathrm{mg}, 0.10$ $\mathrm{mmol}), \mathrm{UO}_{2}\left(\mathrm{NO}_{3}\right)_{2} \cdot 6 \mathrm{H}_{2} \mathrm{O}(35 \mathrm{mg}, 0.07 \mathrm{mmol}), \mathrm{KNO}_{3}(10 \mathrm{mg}, 0.10 \mathrm{mmol})$, and $18 \mathrm{C} 6$ (26 mg, 0.10 mmol) were dissolved in water $(0.6 \mathrm{~mL})$. Yellow crystals of complex 4 were obtained within one month (10 mg, 27\% yield based on U). Anal. Calcd for $\mathrm{C}_{112} \mathrm{H}_{175} \mathrm{~K}_{5} \mathrm{O}_{118} \mathrm{U}_{12}: \mathrm{C}, 20.82 ; \mathrm{H}, 2.73$. Found: C, 20.93; H, 2.77\%. 
$\left[\left(\mathrm{UO}_{2}\right)_{12} \mathrm{~K}_{5}(\mathrm{rac}-\mathrm{t}-1,2-\mathrm{chdc})_{4}\left(\mathrm{C}_{2} \mathrm{O}_{4}\right)_{10}(18 \mathrm{C} 6)_{5}(\mathrm{OH})\left(\mathrm{H}_{2} \mathrm{O}\right)_{3}\right] \cdot 4 \mathrm{H}_{2} \mathrm{O}$ (5). rac-t-1,2-chdcH $\mathrm{H}_{2}(17 \mathrm{mg}$, $0.10 \mathrm{mmol}), \mathrm{UO}_{2}\left(\mathrm{NO}_{3}\right)_{2} \cdot 6 \mathrm{H}_{2} \mathrm{O}(35 \mathrm{mg}, 0.07 \mathrm{mmol}), \mathrm{KNO}_{3}(10 \mathrm{mg}, 0.10 \mathrm{mmol})$, and $18 \mathrm{C} 6(26 \mathrm{mg}$, $0.10 \mathrm{mmol})$ were dissolved in water $(0.6 \mathrm{~mL})$. Yellow crystals of complex 5 were obtained within two months (13 mg, 34\% yield based on $\mathrm{U}$ ). Anal. Calcd for $\mathrm{C}_{112} \mathrm{H}_{175} \mathrm{~K}_{5} \mathrm{O}_{118} \mathrm{U}_{12}: \mathrm{C}, 20.82 ; \mathrm{H}, 2.73$. Found: C, 20.85; H, 2.77\%.

$\left[\left(\mathrm{UO}_{2}\right)_{8} \mathrm{~K}_{4}(\mathrm{rac}-\mathrm{t}-1,2-\mathrm{chdc})_{4}\left(\mathrm{C}_{2} \mathrm{O}_{4}\right)_{6}(18 \mathrm{C} 6)_{3}\left(\mathrm{H}_{2} \mathrm{O}\right)_{2}\right]$ (6). rac-t-1,2-chdcH $2(17 \mathrm{mg}, 0.10 \mathrm{mmol})$, $\mathrm{UO}_{2}\left(\mathrm{NO}_{3}\right)_{2} \cdot 6 \mathrm{H}_{2} \mathrm{O}(35 \mathrm{mg}, 0.07 \mathrm{mmol}), \mathrm{KNO}_{3}(10 \mathrm{mg}, 0.10 \mathrm{mmol})$, and $18 \mathrm{C} 6(26 \mathrm{mg}, 0.10 \mathrm{mmol})$ were dissolved in water $(0.6 \mathrm{~mL})$. Yellow crystals of complex 6 were obtained in low yield within one month.

Crystallography. The data were collected at 150(2) K on a Nonius Kappa-CCD area detector diffractometer ${ }^{26}$ using graphite-monochromated Mo K $\alpha$ radiation $(\lambda=0.71073 \AA)$. The crystals were introduced into glass capillaries with a protective coating of Paratone-N oil (Hampton Research). The unit cell parameters were determined from ten frames, then refined on all data. The data (combinations of $\varphi$ - and $\omega$-scans with a minimum redundancy of 4 for $90 \%$ of the reflections) were processed with HKL2000. ${ }^{27}$ Absorption effects were corrected empirically with the program SCALEPACK. ${ }^{27}$ The structures were solved by intrinsic phasing with SHELXT, ${ }^{28}$ expanded by subsequent difference Fourier synthesis and refined by full-matrix least-squares on $F^{2}$ with SHELXL-2014. ${ }^{29}$ All non-hydrogen atoms were refined with anisotropic displacement parameters. Specific details for each compound about disorder effects, twinning and restraints are given as Supporting Information. The hydrogen atoms bound to oxygen atoms were retrieved from difference Fourier maps for compounds 1, 4 (except for one solvent water molecule) and 5, but not for $\mathbf{3}$ and $\mathbf{6}$, and the carbon-bound hydrogen atoms were introduced at calculated positions. All 
hydrogen atoms were treated as riding atoms with an isotropic displacement parameter equal to 1.2 times that of the parent atom. Crystal data and structure refinement parameters are given in Table 1. The molecular plots were drawn with ORTEP- $3,{ }^{30}$ and the polyhedral representations with VESTA. ${ }^{31}$ The topological analyses were conducted with TOPOS. ${ }^{32}$

Table 1. Crystal Data and Structure Refinement Details

\begin{tabular}{|c|c|c|c|c|c|c|}
\hline & 1 & 2 & 3 & 4 & 5 & 6 \\
\hline chemical formula & $\mathrm{C}_{26} \mathrm{H}_{50} \mathrm{O}_{29} \mathrm{U}_{3}$ & $\mathrm{C}_{42} \mathrm{H}_{60} \mathrm{Na}_{2} \mathrm{O}_{38} \mathrm{U}_{4}$ & $\mathrm{C}_{40} \mathrm{H}_{59} \mathrm{~K}_{2} \mathrm{O}_{38.5} \mathrm{U}_{4}$ & $\mathrm{C}_{112} \mathrm{H}_{175} \mathrm{~K}_{5} \mathrm{O}_{118} \mathrm{U}_{12}$ & $\mathrm{C}_{112} \mathrm{H}_{175} \mathrm{~K}_{5} \mathrm{O}_{118} \mathrm{U}_{12}$ & $\mathrm{C}_{80} \mathrm{H}_{116} \mathrm{~K}_{4} \mathrm{O}_{76} \mathrm{U}_{8}$ \\
\hline$M\left(\mathrm{~g} \mathrm{~mol}^{-1}\right)$ & 1540.75 & 2171.00 & 2186.19 & 6461.37 & 6461.37 & 4354.36 \\
\hline cryst syst & triclinic & triclinic & triclinic & triclinic & triclinic & triclinic \\
\hline space group & $P_{1}^{-1}$ & $P_{1}^{-1}$ & $P_{\overline{1}}$ & $P 1$ & $P_{\overline{1}}$ & $P_{\overline{1}}$ \\
\hline$a(\AA)$ & $9.9738(4)$ & $10.5651(8)$ & $10.4480(7)$ & $10.6465(5)$ & $10.6680(4)$ & $10.7719(7)$ \\
\hline$b(\AA)$ & $11.6116(6)$ & $15.3082(9)$ & $16.7418(11)$ & $19.1260(6)$ & $19.1433(5)$ & $17.0342(10)$ \\
\hline$c(\AA)$ & $19.3210(9)$ & $19.5404(11)$ & $18.2100(13)$ & $23.2639(13)$ & $23.2573(10)$ & $18.4293(9)$ \\
\hline$\alpha(\mathrm{deg})$ & $91.495(2)$ & $75.056(5)$ & $87.039(4)$ & $104.180(3)$ & $104.615(2)$ & $114.598(3)$ \\
\hline$\beta($ deg $)$ & $90.207(3)$ & $86.203(5)$ & $74.646(3)$ & $95.850(2)$ & $96.038(2)$ & $93.203(3)$ \\
\hline$\gamma(\operatorname{deg})$ & $107.955(3)$ & $81.772(4)$ & $78.133(4)$ & $99.702(3)$ & $99.610(2)$ & $94.870(4)$ \\
\hline$V\left(\AA^{3}\right)$ & $2127.74(17)$ & $3020.6(3)$ & $3005.9(4)$ & $4476.0(4)$ & $4477.1(3)$ & $3048.1(3)$ \\
\hline$Z$ & 2 & 2 & 2 & 1 & 1 & 1 \\
\hline$D_{\text {calcd }}\left(\mathrm{g} \mathrm{cm}^{-3}\right)$ & 2.405 & 2.387 & 2.415 & 2.397 & 2.396 & 2.372 \\
\hline$\mu(\mathrm{Mo} \mathrm{K} \alpha)\left(\mathrm{mm}^{-1}\right)$ & 11.484 & 10.805 & 10.982 & 11.039 & 11.036 & 10.829 \\
\hline$F(000)$ & 1428 & 2012 & 2026 & 2990 & 2990 & 2016 \\
\hline reflns collcd & 108676 & 154921 & 151304 & 228056 & 204195 & 124711 \\
\hline indep reflns & 8080 & 11454 & 11414 & 33720 & 16977 & 11480 \\
\hline obsd reflns $[I>2 \sigma(I)]$ & 7213 & 9269 & 8581 & 27953 & 14386 & 7435 \\
\hline$R_{\text {int }}$ & 0.049 & 0.054 & 0.074 & 0.043 & 0.043 & 0.054 \\
\hline params refined & 289 & 813 & 783 & 2235 & 1126 & 782 \\
\hline$R_{1}$ & 0.048 & 0.060 & 0.054 & 0.053 & 0.035 & 0.056 \\
\hline$w R_{2}$ & 0.122 & 0.162 & 0.151 & 0.131 & 0.083 & 0.137 \\
\hline$S$ & 1.093 & 1.066 & 1.019 & 1.027 & 1.074 & 1.032 \\
\hline$\Delta \rho_{\min }\left(\mathrm{e} \AA^{-3}\right)$ & -1.77 & -2.77 & -2.38 & -1.50 & -1.34 & -1.68 \\
\hline$\Delta \rho_{\max }\left(\mathrm{e} \AA^{-3}\right)$ & 3.63 & 4.46 & 3.69 & 1.67 & 1.77 & 2.81 \\
\hline
\end{tabular}

Luminescence Measurements. Emission spectra were recorded on solid samples using a Horiba-Jobin-Yvon Fluorolog spectrofluorometer. The powdered compound was pressed between two silica plates which were mounted such that the faces were oriented vertically and at $45^{\circ}$ to the incident excitation radiation. An excitation wavelength of $420 \mathrm{~nm}$, a commonly used point although only part of a broad manifold, was used in all cases and the emission was monitored between 450 and $650 \mathrm{~nm}$. 


\section{RESULTS AND DISCUSSION}

Synthesis. In general, the conditions of solvothermal syntheses, ${ }^{33}$ involving non-aqueous or mixed solvents under moderately high to relatively extreme temperatures and pressures, are such that very little quantitative data are available concerning complexation equilibria, reagent acidity or basicity, reaction rates and the stability of all reactant species. A consequence of this is that the products of solvo- or hydrothermal syntheses are frequently found to contain "unexpected" components, well-known examples of this being the presence of formate or dimethylammonium ions due to the hydrolysis of dimethylformamide when used as a cosolvent with water. ${ }^{23,24,34}$ Another example is provided in the frequently observed presence of oxalate anion in complexes isolated from media where this anion was not initially present, ${ }^{35}$ although here speculation as to its origin has encompassed a variety of pathways, full elucidation having only been performed in some specific cases. ${ }^{36,37}$ In all six uranyl complexes reported here, obtained from media incorporating crown ethers, oxalate is found as a coligand, although not initially present. Given that the cyclohexanedicarboxylate ligands have been used in solvo-hydrothermal syntheses of their uranyl ion complexes in the absence of crown ethers and have not been found to form complexes also incorporating oxalate, ${ }^{15,22,23}$ an obvious implication from this work is that crown ethers, over a long reaction period under hydrothermal conditions and in the presence of uranyl nitrate, can be converted to oxalate. This was somewhat unexpected given that one of the first demonstrations of the unique properties of crown ethers was that of the solubilisation of as powerful an oxidant as $\mathrm{KMnO}_{4}$ in apolar solvents ${ }^{38}$ and that crown ethers have been used as phase-transfer catalysts in a wide variety of oxidations. ${ }^{6}$ An obvious reaction pathway to oxalate would be that of acid-catalysed cleavage of the macrocyclic ether to give ethylene glycol followed by oxidation of this diol to oxalate, an oxidation known to occur with various metal nitrates, ${ }^{39}$ although it has only been studied in detail in biological systems, where several intermediates have been identified. ${ }^{40}$ Given the 
instability of uranyl ion complexes of crown ethers in pure aqueous media, ${ }^{41-43}$ it is assumed that intramolecular oxidation of the uranyl-bound crowns would be an unlikely pathway, although it cannot be excluded a priori.

Preliminary investigation using ${ }^{1} \mathrm{H}$ NMR spectroscopy of the reactions occurring in a $\mathrm{D}_{2} \mathrm{O}$ solution of $\mathrm{UO}_{2}\left(\mathrm{NO}_{3}\right)_{2} \cdot 6 \mathrm{D}_{2} \mathrm{O}$ (prepared by evaporating a solution of the hexa(protiohydrate) in $\mathrm{D}_{2} \mathrm{O}$ to dryness twice), $18 \mathrm{C} 6, \mathrm{KNO}_{3}$ and $t-1,2-\mathrm{chdcH}_{2}$ heated in a sealed tube in the dark at $120^{\circ} \mathrm{C}$ for 2 months provided evidence of the very slow decomposition of the crown ether, although only through ring opening. A much faster reaction, complete within a few days, was that of exchange of the methine protons of the diacid and this was accompanied by the formation of some crystalline, pale yellow precipitate. The NMR spectra that were recorded every week did not show any significant change up to 8 weeks. It is important to mention that the solid precipitate previously discussed seems to be degraded after 6 weeks, yielding a brownish solid. Thus, a more prolonged study of the apparently very slow reactions in the preparative media would be necessary to establish clearly the origin of the oxalate anions. Further, the possibility that the reaction may be subject to photocatalysis would need to be explored simultaneously.

On the assumption that the charge on uranyl ion plus alkali metal ion aggregates in solid products would be balanced by that on the dicarboxylate anions derived from the cyclohexane dicarboxylic acids employed in the present work, reaction mixtures were prepared with a uranium: $\mathrm{chdcH}_{2}$ ratio of (approximately) 1:1.5. In the event, the generation of and cocrystallisation with oxalate during the syntheses led to uranium:chdc ${ }^{2-}$ stoichiometries varying from 1.5:1 (complex 1), through 2:1 (complexes 2, 3 and $\mathbf{6}$ ) to 3:1 (complexes $\mathbf{4}$ and 5). Given the long reaction periods ( 1 or 2 months) at an elevated temperature $\left(140^{\circ} \mathrm{C}\right)$ and the presence of both nitrate and uranyl ions as potential oxidants (one quite possibly catalysing reaction of the other), it is unsurprising that some conversion of the organic reaction mixture components to oxalate might 
occur. The degree of conversion is a factor which must limit the yield of the products isolated, clearly in a complicated manner given the varied stoichiometry in regard to the uranium:oxalate ratios (3:1 for $\mathbf{1}, 4: 3$ for $\mathbf{2 , 3}$ and $\mathbf{6}$, and $6: 5$ for $\mathbf{4}$ and $\mathbf{5}$ ).

Crystal Structures. The compound $\left[\left(\mathrm{UO}_{2}\right)_{2}(c-1,3-c h d c)_{2}\left(\mathrm{C}_{2} \mathrm{O}_{4}\right)\right]\left[\mathrm{UO}_{2}\left(\mathrm{H}_{2} \mathrm{O}\right)_{5}\right]$. $(12 \mathrm{C} 4) \cdot 2 \mathrm{H}_{2} \mathrm{O}(\mathbf{1})$ is the third uranyl complex with $1,3-\operatorname{chdc}^{2-}$, after $\left[\mathrm{UO}_{2}(c-1,3-c h d c)\left(\mathrm{H}_{2} \mathrm{O}\right)\right]$ and $\left[\left(\mathrm{UO}_{2}\right)_{2}(c / t-1,3-\mathrm{chdc})_{2}\left(\mathrm{H}_{2} \mathrm{O}\right)_{3}\right] \cdot(15 \mathrm{C} 5) \cdot \mathrm{H}_{2} \mathrm{O} .{ }^{15}$ Both the latter complex and $\mathbf{1}$ were synthesized in the presence of $\mathrm{Li}^{+}$cations, which are absent from the final products, the crown ether in both cases being uncoordinated. $\mathbf{1}$ is thus the only complex in the present series to involve the 1,3 isomer of $\operatorname{chdc}^{2-}$ and to include a free crown ether molecule. The asymmetric unit in $\mathbf{1}$ contains two uranyl cations, two 1,3-chdc ${ }^{2-}$ and one oxalate anions being part of an anionic polymer, one $\mathrm{UO}_{2}\left(\mathrm{H}_{2} \mathrm{O}\right)_{5}{ }^{2+}$ cation, and the free 12C4 (Figure 1). Atoms U1 and U2 are both chelated by two carboxylate groups from 1,3-chdc ${ }^{2-}$ ligands and by one oxalate anion, and they are thus in hexagonal bipyramidal environments, while the penta-aqua coordinated U3 is pentagonal bipyramidal; all $\mathrm{U}-\mathrm{O}$ bond lengths are unexceptional. Although the synthesis has been made from a mixture of the cis and trans isomers of 1,3-chdcH $\mathrm{H}_{2}$, one of the ligands in $\mathbf{1}$ is cis, and the second one, linking U2 centres, is affected by disorder (see Supporting Information) corresponding most probably to the superposition of two cis molecules. One of the complexes previously reported contains also a disordered cis molecule, while the compound including 15C5 contains both the cis and trans isomers. Both $c-1,3-\operatorname{chdc}^{2-}$ ligands in $\mathbf{1}$ are in the chair conformation with the carboxylate groups in equatorial position. Two linear $\mathrm{UO}_{2}(c-1,3-c h d c)$ chains are linked by the bridging oxalate anions to form a quasiplanar ladderlike ribbon directed along the $a$ axis. While the $c-1,3-\operatorname{chdc}^{2-}$ ligands 

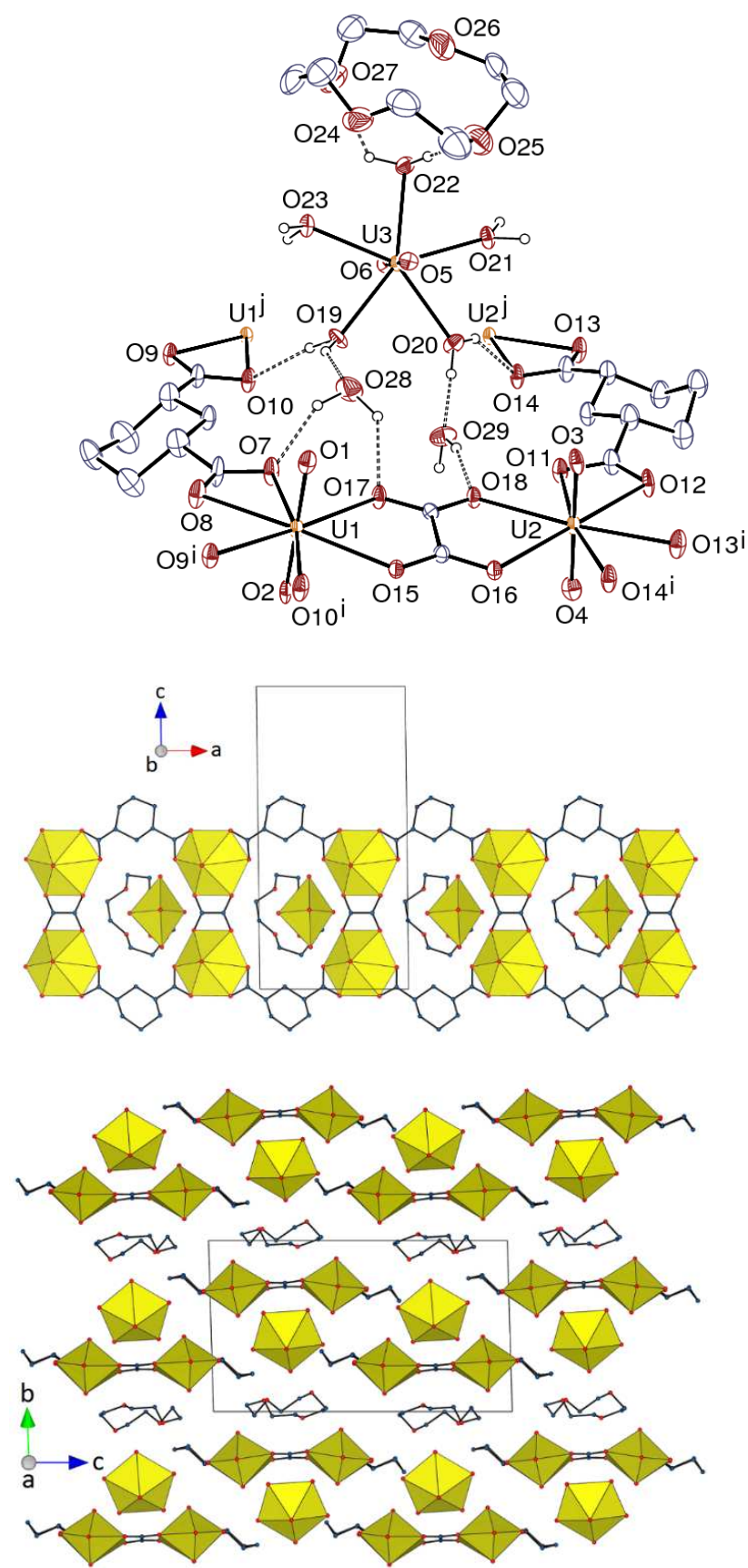

Figure 1. Top: View of compound 1. Displacement ellipsoids are drawn at the $30 \%$ probability level. Carbon-bound hydrogen atoms are omitted and hydrogen bonds are shown as dashed lines. Symmetry codes: $\mathrm{i}=x+1, y, z ; \mathrm{j}=x-1$, $y, z$. Middle: View of the 1D polymeric ribbon with counterions and crown ether molecules. Uranium coordination polyhedra are colored yellow. Bottom: Packing with chains viewed end-on. Solvent molecules and hydrogen atoms are omitted in the last two views. Only one position of the disordered part is shown in all views. 
link either $\mathrm{U} 1$ or $\mathrm{U} 2$ into chains via the formation of separate four-membered chelate rings by each carboxylate, oxalate forms rungs of the overall ladder structure by bridging U1 and U2 centres via the formation of two five-membered chelate rings. Overall, consecutive U1 and U2 pairs form part of 24-membered rings. The 10 protons of the $\mathrm{UO}_{2}\left(\mathrm{H}_{2} \mathrm{O}\right)_{5}{ }^{2+}$ cation and those of the two lattice water molecules are involved in hydrogen bonding interactions with both carboxylate and crown ether oxygen acceptors $\left[\mathrm{O} \cdots \mathrm{O} 2.533(12)-3.091(11) \AA\right.$, O-H $\left.\cdots \mathrm{O} 116-174^{\circ}\right]$, these interactions being familiar modes of interaction for crown ethers in general. ${ }^{10}$ The hydrogen bonding interactions between anionic ribbons and counterions (some of them mediated by the lattice water molecules) result in the formation of double layers parallel to $\left(\begin{array}{lll}0 & 1 & 0\end{array}\right)$ separated by layers of $12 \mathrm{C} 4$ molecules. Further hydrogen bonding involving the crown ether and both the counterions and uncoordinated water molecules means that the complete lattice can be considered as a three-dimensional (3D) hydrogen bond polymer. $\mathrm{CH}$ (crown ether) $\cdots \mathrm{O}$ (oxo, carboxylate) interactions only just detectable on the Hirshfeld surface ${ }^{44}$ of the asymmetric unit, calculated with CrystalExplorer, ${ }^{45}$ reinforce the

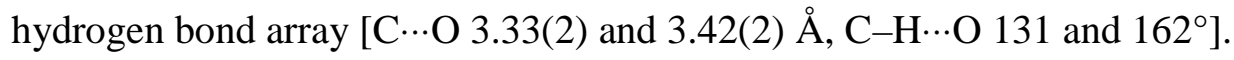

$\left[\left(\mathrm{UO}_{2}\right)_{4} \mathrm{Na}_{2}(c-1,2-\mathrm{chdc})_{2}\left(\mathrm{C}_{2} \mathrm{O}_{4}\right)_{3}(15 \mathrm{C} 5)_{2}\right](2)$ is one of two complexes obtained from the $c$ is isomer of 1,2-chdcH $\mathrm{H}_{2}$, no uranyl complex with this ligand having been reported previous to this work. Uranyl complexes with this isomer appear to be generally much less amenable to crystallization than those of the trans isomer, either in its racemic or pure enantiomeric $(1 R, 2 R$ form). ${ }^{22,23}$ The asymmetric unit in 2 contains four uranyl ions, two $c-1,2$-chdc ${ }^{2-}$ ligands in the chiral chair conformation with one carboxylate group equatorial and the other axial, four oxalate anions, two of which are centrosymmetric, and two $\mathrm{Na}(15 \mathrm{C} 5)$ moieties (Figure 2). Atoms U1 and U3 are both chelated between the two carboxylate groups of one $c-1,2-\mathrm{chdc}^{2-}$ ligand, bound to one more 

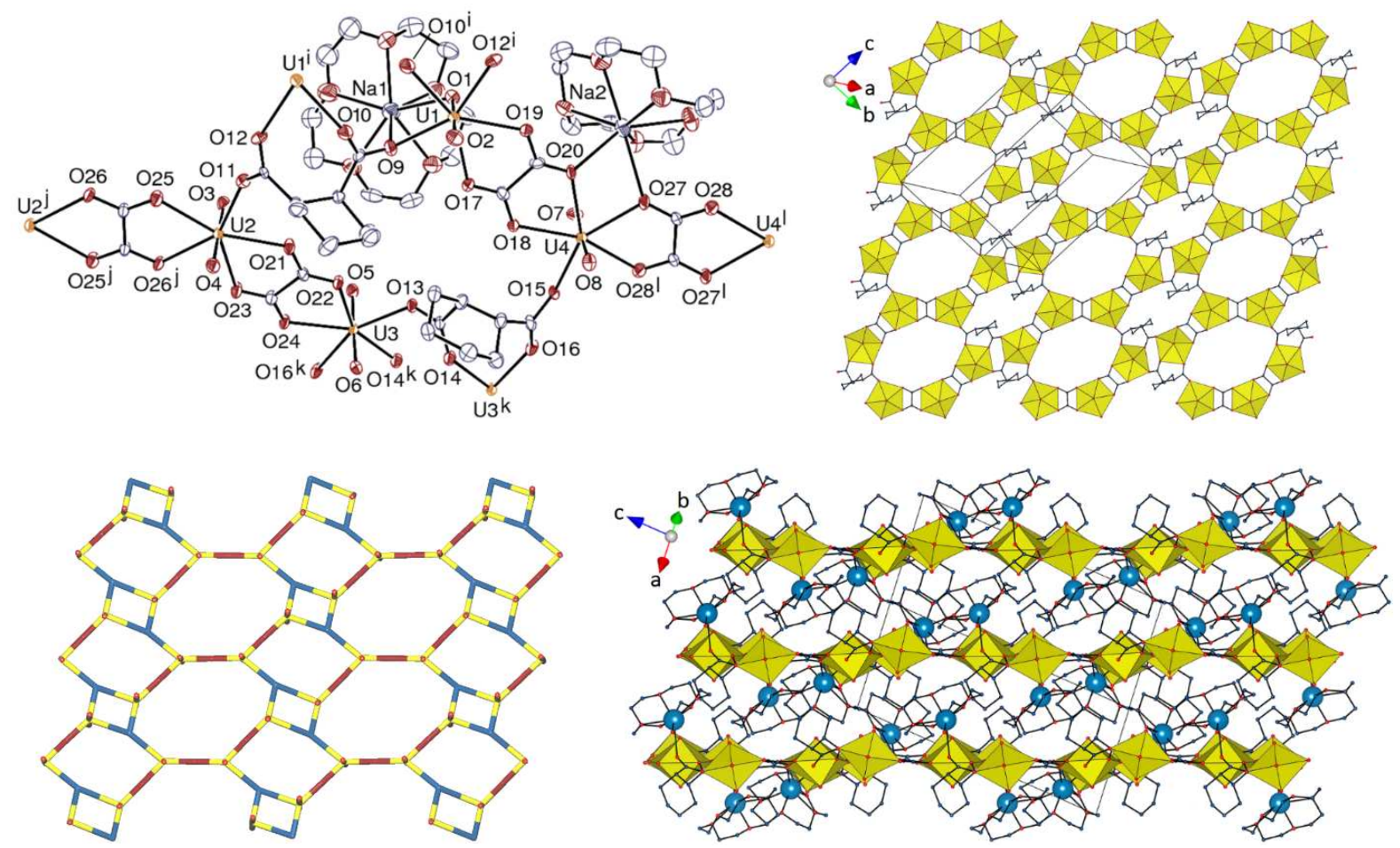

Figure 2. Top left: View of compound 2. Displacement ellipsoids are drawn at the $30 \%$ probability level. Symmetry codes: $\mathrm{i}=1-x, 1-y, 1-z ; \mathrm{j}=2-x, 2-y, 1-z ; \mathrm{k}=1-x, 2-y,-z ; 1=-x, 1-y,-z$. Top right: View of the $2 \mathrm{D}$ assembly with $\mathrm{Na}(15 \mathrm{C} 5)$ units omitted. Bottom left: Nodal representation of the 2D network (yellow: uranium, red: oxygen, blue: $c-1,2-$ chdc $^{2-}$ ligand, dark red: oxalate ligand). Bottom right: View of the packing with uranium polyhedra colored yellow and sodium atoms shown as blue spheres. Only one position of the disordered part is shown and hydrogen atoms are omitted in all views.

carboxylate oxygen atom from another ligand, and chelated by an oxalate anion, while atoms U2 and U4 are chelated by two oxalate anions and bound to only one carboxylate oxygen atom from a $c-1,2-$ chdc $^{2-}$ ligand, all uranium atoms being thus in pentagonal bipyramidal environments with $\mathrm{U}-\mathrm{O}$ bond lengths in the usual ranges. While all oxalate ligands are bound in a bridging tetrahapto mode as in complex $\mathbf{1}$, the $c-1,2-\operatorname{chdc}^{2-}$ ligands are unlike the $c-1,3-\operatorname{chdc}^{2-}$ ligands of $\mathbf{1}$ in that they coordinate in exclusively a $\operatorname{bis}\left(\mu_{2}-\kappa^{1} O: \kappa^{1} O^{\prime}\right)$ doubly-bridging bidentate mode, although with one uranyl ion being chelated between the two carboxylate groups of each ligand. As a result of 
bridging by both ligands, each uranium centre has a near neighbour of the same type, with U1 $\cdots \mathrm{U} 1$ and $\mathrm{U} 3 \cdots \mathrm{U} 3$ pairs being bridged by enantiomeric pairs of $c-1,2-\mathrm{chdc}^{2-}$ ligands while $\mathrm{U} 2 \cdots \mathrm{U} 2$ and U4 $\cdots$ U4 pairs are bridged by oxalate. Further bridging interactions mean U1 is also linked to U2 ( $c$-1,2-chdc ${ }^{2-}$ bridge) and $\mathrm{U} 4$ (oxalate), as is $\mathrm{U} 3$ but by the inverse bridging arrangement. The uranium centres and carboxylate ligands alone form a 2D network parallel to $\left(\begin{array}{lll}1 & \overline{1} & \overline{1}\end{array}\right)$ involving fusion of 8-, 22- and 24-membered metallacyclic units, in which all uranium atoms and $c-1,2-$ chdc $^{2-}$ ligands are trigonal nodes while oxalate anions are simple links, and which has the point (Schläfli) symbol $\{4.6 .8\}_{2}\left\{6.8^{2}\right\}$ (first symbol for the $c$-1,2-chdc ${ }^{2-}$ ligands, U1 and U3, second for $\mathrm{U} 2$ and $\mathrm{U} 4)$. It is notable that oxalate ligands alone are known to give a $\left\{6^{3}\right\}$ honeycomb network with tris-chelated uranyl ions. ${ }^{46} 15 \mathrm{C} 5$, conventionally considered best suited to the size of $\mathrm{Na}^{+}$, is indeed found to be bound to this cation [Na-O 2.330(14)-2.537(13) $\mathrm{A}$ ], although the two inequivalent $[\mathrm{Na}(15 \mathrm{C} 5)]^{+}$units are simply decorative to the 2D uranyl coordination polymer. As in simpler species, ${ }^{8,9,47,48}$ the $\mathrm{Na}^{+}$cation lies significantly out of the mean plane of the five oxygen donor atoms of the crown, with displacements of $0.819(10)$ and $0.897(9) \AA$ for $\mathrm{Na} 1$ and $\mathrm{Na} 2$, respectively. Both sodium ions form two additional coordinate bonds oriented away from the crown which here do not increase the dimensionality of the solid state array. $\mathrm{Na} 2$ is thus bound to two carboxylate oxygen atoms from two oxalate anions bound to $\mathrm{U} 4$, and $\mathrm{Na} 1$ to one from a $c-1,2-$ chdc $^{2-}$ ligand bound to U1, with Na-O bond lengths of 2.483(10), 2.602(12) and 2.736(14) $\AA$, respectively, and $\mathrm{Na} 1$ is also coordinated to the uranyl oxo atom $\mathrm{O} 1$ with a bond length of $2.502(11)$ $\AA$, a value within the usual range for these rather common bonds. ${ }^{21,48-54}$ The packing displays an alternation of uranyl-containing polymeric sheets and layers occupied by the $[\mathrm{Na}(15 \mathrm{C} 5)]^{+}$ appendages. In the absence of water molecules, interactions between the sheets appear to involve largely $\mathrm{CH} \cdots \mathrm{O}$ contacts of the polyether units. 
Although the second complex with $c$-1,2-chdc ${ }^{2-}$ ligands, $\quad\left[\left(\mathrm{UO}_{2}\right)_{4} \mathrm{~K}_{2}(c-1,2-\right.$ chdc $\left.)_{2}\left(\mathrm{C}_{2} \mathrm{O}_{4}\right)_{3}(18 \mathrm{C} 6)_{1.5}\left(\mathrm{H}_{2} \mathrm{O}\right)_{1.5}\right](3)$, in which $\mathrm{Na}^{+}$and $15 \mathrm{C} 5$ are replaced by $\mathrm{K}^{+}$and $18 \mathrm{C} 6$, is not isomorphous to $\mathbf{2}$, it crystallizes in the same space group, with unit cell parameters which are not widely different. The asymmetric unit here contains also four uranium atoms, two $c-1,2$-chdc ${ }^{2-}$ ligands in the same conformation as in $\mathbf{2}$, three oxalate anions, and a set of three partly disordered potassium cations (one of them located on an inversion center) and two $18 \mathrm{C} 6$ molecules (one of them centrosymmetric and badly resolved, see Supporting Information), this part of the structure being however somewhat uncertain (Figure 3). The uranyl/c-1,2-chdc ${ }^{2-} /$ oxalate connectivity is the same as in 2 , with formation of a $2 \mathrm{D}$ network subunit of identical topology parallel to (1 $\overline{1} 1)$, and it will not be further described. There is a significant difference in stoichiometry between the two compounds in that the ratio alkali metal/crown ether is $1: 1$ in 2 , but $2: 1.5$ in 3 (and the latter is hydrated), and analysis of the role of $\mathrm{K}^{+}$in the lattice is complicated by partial occupancy and disorder. Atom K1 and its 18C6 ligand have inversion symmetry while K2 is disordered over two positions and bound to a very badly resolved $18 \mathrm{C} 6$ molecule, and $\mathrm{K} 3$, with half occupancy, is only bound to oxalate and water ligands. $\mathrm{K} 1$ and one component of $\mathrm{K} 2$ are bound to the uranyl oxo atoms $\mathrm{O} 1$ (and its symmetry equivalent) and O3, respectively, with $\mathrm{K}-\mathrm{O}$ bond lengths of 2.794(8) and 2.792(12) $\AA$, these values being in good agreement with those usual for such bonds, ${ }^{16,19,21,49,55-}$ ${ }^{64}$ the average value for the 27 cases reported in the CSD (some of which, not cited here, involve $\mathrm{U}^{\mathrm{V}}$ instead of $\mathrm{U}^{\mathrm{VI}}$ ) being $2.76(10) \AA$. In the case of $\mathrm{K} 1$, the location of the cation within the average plane of the crown ether enables bonding on each side, and this cation thus plays an assembling role through linking adjacent sheets. The situation for $\mathrm{K} 2$ is less clear due to disorder, but this cation appears to be bound to two oxalate oxygen atoms on the same side of the crown ether as the oxo atom $\mathrm{O} 3$, and to a disordered water molecule on the other side, the latter being also bound to 

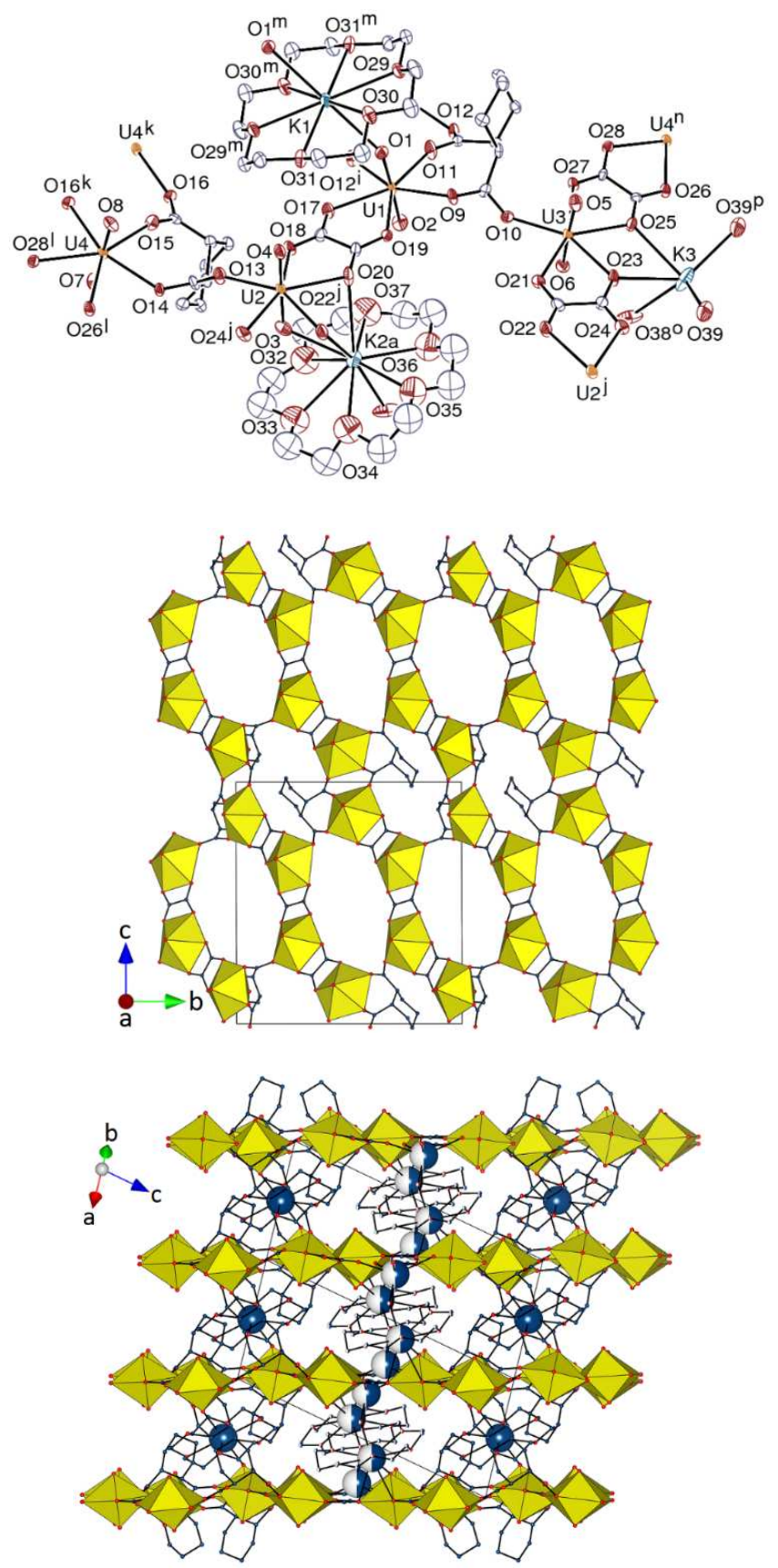

Figure 3. Top: View of compound 3. Displacement ellipsoids are drawn at the $30 \%$ probability level. Symmetry codes: $\mathrm{i}=1-x, 1-y,-z ; \mathrm{j}=-x, 1-y, 1-z ; \mathrm{k}=-x,-y,-z ; \mathrm{l}=x-1, y-1, z ; \mathrm{m}=-x, 1-y,-z ; \mathrm{n}=x+1, y+1, z ; \mathrm{o}=1-x$, $1-y, 1-z ; \mathrm{p}=1-x, 2-y, 1-z$. Middle: View of the uranyl-based 2D subunit. Bottom: View of the 3D framework with uranium polyhedra colored yellow and potassium atoms shown as blue spheres (parti-colored in the case of the disordered cations). Hydrogen atoms are omitted in all views. 
$\mathrm{K} 3$, so that here also intersheet links are present. These different environments for the $\mathrm{K}(18 \mathrm{C} 6)^{+}$ unit are consistent with what is known from the structure of simpler systems where, for example, acetate is chelated to one face ${ }^{65}$ or where amide oxygen donors from a substituted $\mathrm{Co}^{\mathrm{III}}$ porphyrin bind to the opposite faces ( $\mathrm{K}^{+}$thus acting as a bridge for polymer formation) ${ }^{66}$ Bridging by $\mathrm{K}(18 \mathrm{C} 6)^{+}$cations thus generates a 3D framework in compound $\mathbf{3}$, while they are simple decorating species in previously reported uranyl diphosphonate ${ }^{16}$ or selenate ${ }^{17}$ complexes (as well as $\mathrm{K}(15 \mathrm{C} 5)^{+}$ in another selenate complex ${ }^{19}$ ). Since the uranyl oxo groups generally point outside on the surfaces of uranyl-based polymeric layers, oxo bonding of the alkali cations is essential here, and the planar geometry of $\mathrm{K}(18 \mathrm{C} 6)^{+}$makes it perfectly adapted to interlayer insertion.

The two complexes $\left[\left(\mathrm{UO}_{2}\right)_{12} \mathrm{~K}_{5}(R-t-1,2 \text {-chdc })_{4}\left(\mathrm{C}_{2} \mathrm{O}_{4}\right)_{10}(18 \mathrm{C} 6)_{5}(\mathrm{OH})\left(\mathrm{H}_{2} \mathrm{O}\right)_{3}\right] \cdot 4 \mathrm{H}_{2} \mathrm{O}(4)$ and $\left[\left(\mathrm{UO}_{2}\right)_{12} \mathrm{~K}_{5}(\text { rac-t-1,2-chdc })_{4}\left(\mathrm{C}_{2} \mathrm{O}_{4}\right)_{10}(18 \mathrm{C} 6)_{5}(\mathrm{OH})\left(\mathrm{H}_{2} \mathrm{O}\right)_{3}\right] \cdot 4 \mathrm{H}_{2} \mathrm{O} \quad$ (5) involve either the pure enantiomeric $(1 R, 2 R)$ or the racemic form of $t-1,2-\mathrm{chdc}^{2-}$. They have identical composition and crystallize with very close unit cell parameters, either in the non-centrosymmetric Sohncke group $P 1$, or the centrosymmetric group $P \overline{\mathbf{1}}$. Complex $\mathbf{4}$ is a large species, with an asymmetric unit containing as many as twelve uranyl and five potassium cations, four $t-1,2-\operatorname{chdc}^{2-}$, ten oxalate and five 18C6 ligands, as well as hydroxide and water ligands or solvents, while the asymmetric unit in $\mathbf{5}$ is half as large. The structures of complexes $\mathbf{4}$ and $\mathbf{5}$ are represented in Figures 4 and $\mathbf{5}$, respectively. Four different environments are found for uranyl ions in both compounds, all involving five equatorial donors. The most common, previously found in complexes $\mathbf{2}$ and $\mathbf{3}$, corresponds to double chelation by oxalate anions and coordination to one carboxylate donor from $t$-1,2-chdc ${ }^{2-}$ (atoms U3, U5, U6, U8, U10 and U11 in 4, U1, U3 and U5 in 5). The three other types of environments are represented in equal numbers. One of them, also found in $\mathbf{2}$ and $\mathbf{3}$, involves chelation between two carboxylate groups of one $t-1,2-\operatorname{chdc}^{2-}$ ligand, chelation by oxalate and 

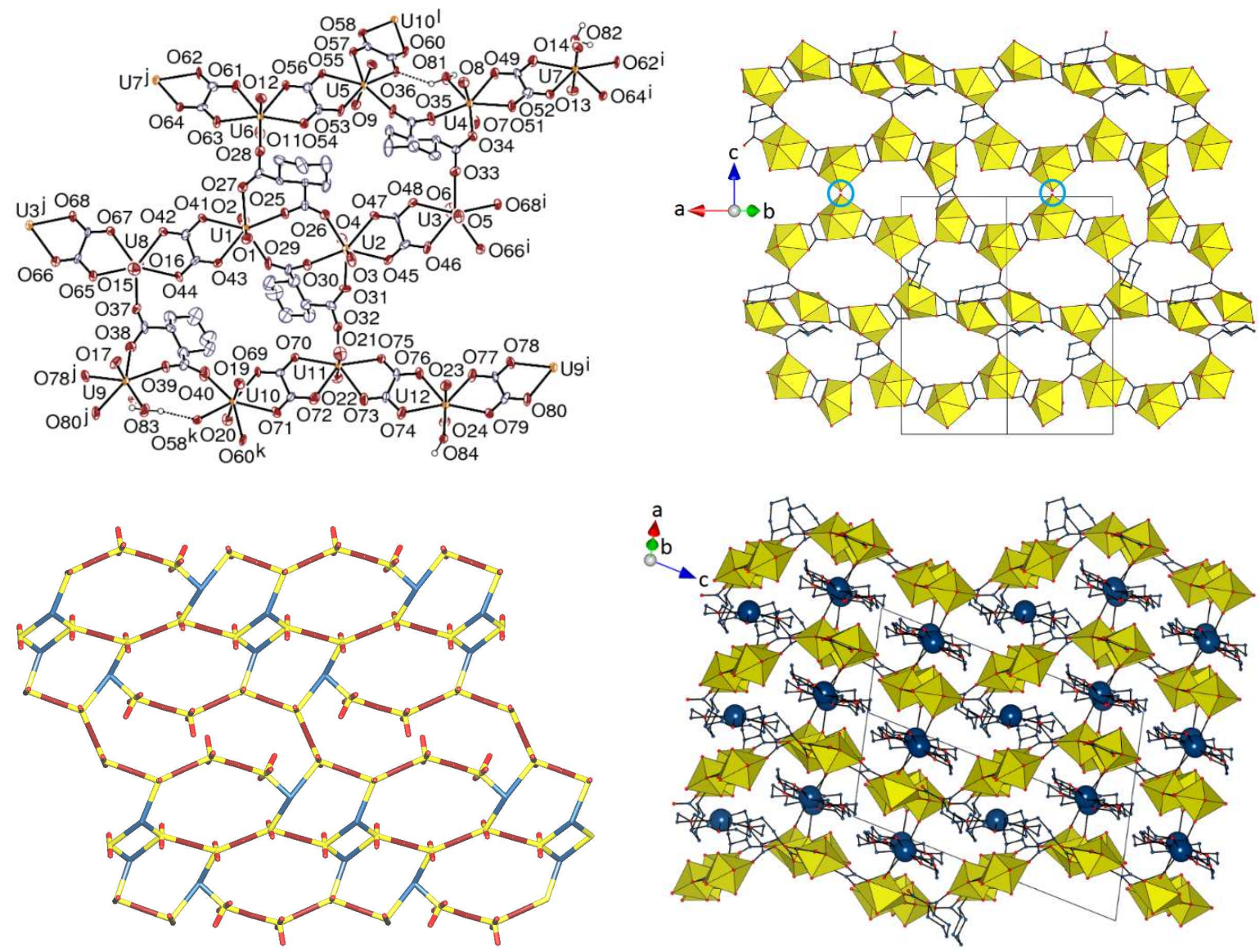

Figure 4. Top left: View of compound 4, with K(18C6) groups omitted for clarity. Displacement ellipsoids are drawn at the $50 \%$ probability level. Carbon-bound hydrogen atoms are omitted, and hydrogen bonds are shown as dashed lines. Symmetry codes: $\mathrm{i}=x-1, y+1, z ; \mathrm{j}=x+1, y-1, z ; \mathrm{k}=x+1, y, z+1 ; 1=x-1, y, z-1$. Top right: View of the uranyl-based 2D subunit with the location of intrasheet water-hydroxide hydrogen bonding indicated by blue circles. Bottom left: Nodal representation of the 2D network subunit (yellow: uranium, red: oxygen, blue: $t-1,2-$ chdc $^{2-}$ ligand, dark red: oxalate ligand). Bottom right: View of the 3D framework with uranium polyhedra colored yellow and potassium atoms shown as blue spheres. Only one position of the disordered atoms is shown and solvent molecules are omitted in all views. 


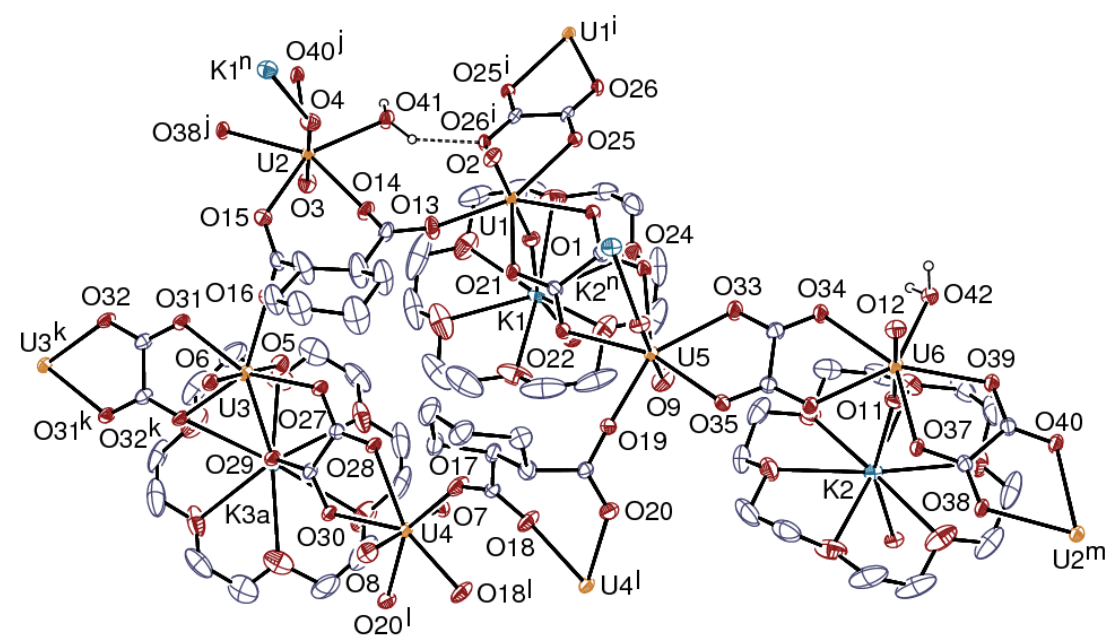

Figure 5. View of compound 5. Displacement ellipsoids are drawn at the $30 \%$ probability level. Only one position of the disordered atoms is shown, solvent molecules and carbon-bound hydrogen atoms are omitted, and the hydrogen bond is shown as a dashed line. Symmetry codes: $\mathrm{i}=1-x, 1-y, 1-z ; \mathrm{j}=x+1, y-1, z ; \mathrm{k}=1-x,-y,-z ; 1=-x, 1-$ $y,-z ; \mathrm{m}=x-1, y+1, z ; \mathrm{n}=x+1, y, z$. The polymeric arrangement is analogous to that in 4 .

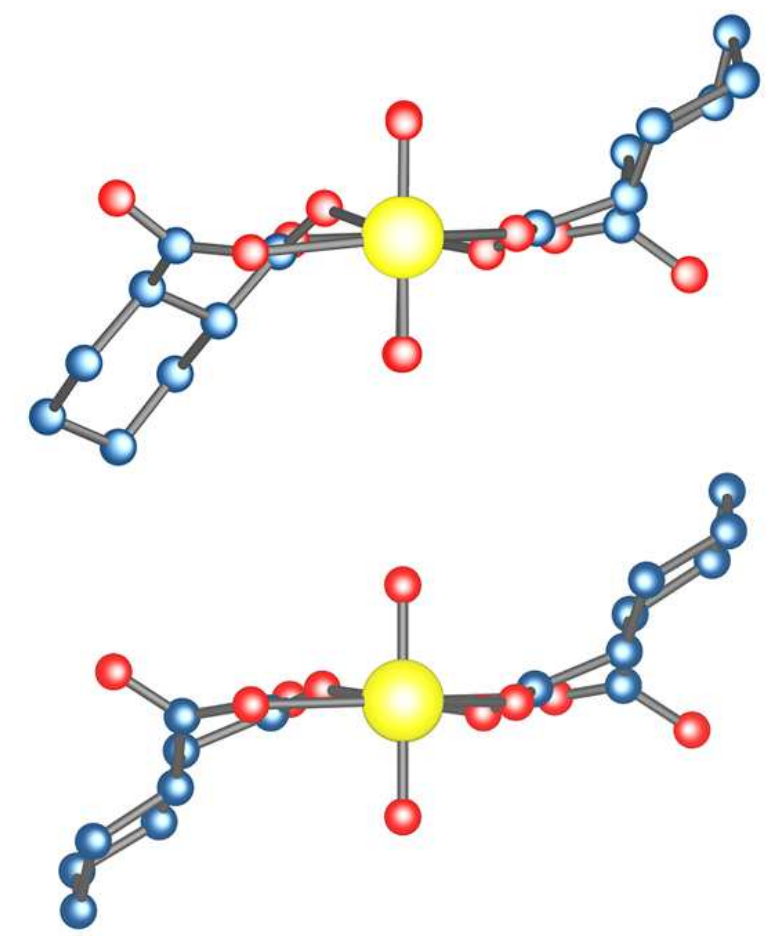

Figure 6. Comparison of the uranyl dimeric units with double $t-1,2-\operatorname{chdc}^{2-}$ bridges viewed down the U-U axis in 4 (top, atoms $\mathrm{U} 1$ and $\mathrm{U} 2$ ), and $\mathbf{5}$ (bottom, atom U4 and its image by inversion). 
bonding to one donor from another $t-1,2-\operatorname{chdc}^{2-}$ ligand (U1 and $\mathrm{U} 2$ in $\mathbf{4}$, U4 in 5). The last two display bonding to one terminal water molecule or hydroxide anion, and chelation by either one $t$ 1,2-chdc ${ }^{2-}$ and one oxalate ligand (U4 and U9 in 4, U2 in 5), or two oxalate ligands (U7 and U12 in $\mathbf{4}$, U6 in 5, which have thus no direct interaction with a $t-1,2-\mathrm{chdc}^{2-}$ ligand). Considering the $t$ 1,2-chdc ${ }^{2-}$ ligands, all in the chair conformation with both carboxylate groups equatorial, their bonding mode to three uranium centres, with 7-membered chelation of one of them, is that found in $\mathbf{2}$ and $\mathbf{3}$, and the oxalate anions all act as tetrahapto bridging species involving 5 -membered

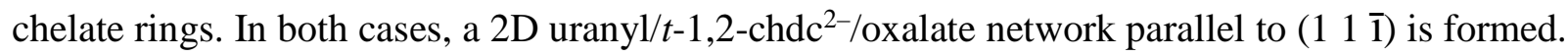
The four (in 4) or two (in 5) uranium atoms bound to terminal water or hydroxide anions are simple links, as well as the oxalate ligands, and the network has the point symbol $\left\{4.6^{2}\right\}_{2}\left\{6.8^{2}\right\}\left\{6^{2} .8\right\}_{2}\left\{6^{3}\right\}$ for both complexes. It is notable that, in $\mathbf{4}$, the water ligand (O82) bound to $\mathrm{U} 7$ and the hydroxide ligand (O84) bound to U12 (with possible disorder between them, see Supporting Information) lie close to one another in the pinched central part of the largest rings in the network, and are hydrogen bonded to one another [O $82 \cdots \mathrm{O} 842.459(17) \AA$, O $\left.82-\mathrm{H} \cdots \mathrm{O} 84115^{\circ}\right]$. The same occurs in $\mathbf{5}$ for atom O42, which is a disordered mixture of water and hydroxide bound to U6 (see Supporting Information), and its symmetry equivalent $\left[\mathrm{O} 42 \cdots \mathrm{O} 42^{\mathrm{ii}} 2.462(10) \AA, \mathrm{O} 42-\mathrm{H} \cdots \mathrm{O} 42^{\mathrm{ii}} 145^{\circ}\right.$, symmetry code ii $=-x, 2-y, 1-z]$. Analysis of the function of the five (in $\mathbf{4}$ ) or three (in $\mathbf{5}$, one of them with inversion symmetry) inequivalent $\mathrm{K}(18 \mathrm{C} 6)^{+}$units in the lattice is complicated by disorder in the case of $\mathrm{K} 5$ or $\mathrm{K} 3$ in $\mathbf{4}$ and $\mathbf{5}$, respectively, but all others consist of a trans$\left[\mathrm{K}(18 \mathrm{C} 6)(\text { uranyl-O })_{2}\right]$ species providing links between the sheets of $2 \mathrm{D}$ uranyl coordination polymers and thus having the effect of increasing the polymer dimensionality, a 3D framework being formed in both cases. The $\mathrm{K}-\mathrm{O}$ (oxo) bond lengths are in the ranges of 2.64(2)-2.81(2) $\AA$ in 4 and 2.656(6)-2.771(6) $\AA$ in 5, and they are thus in agreement with the usual values (see above). 
When viewed with the uranyl-containing sheets edge-on, the assembly displays an alternation of undulating $2 \mathrm{D}$ subunits and separating layers of $\mathrm{K}(18 \mathrm{C} 6)^{+}$counterions, the crown ether molecules being roughly parallel to the layer average plane. Previous experience ${ }^{22,23}$ of the synthesis of uranyl ion complexes of both racemic and enantiomerically pure $t-1,2-\operatorname{chdc}^{2-}$ suggests that any difference between complexes $\mathbf{4}$ and $\mathbf{5}$ should be expected to be quite subtle, and indeed this appears to be so. Viewed in profile, the undulating sheets in $\mathbf{4}$ and $\mathbf{5}$ are virtually indistinguishable from one another despite the fact that the sheet in complex $\mathbf{5}$ contains both enantiomers of the ligand. Consideration of, for example, the 8-membered metallacyclic rings present in both shows how minor changes in orientation of the dicarboxylate ligands allow the centrosymmetric structure of $\mathbf{5}$ to be dimensionally very close to the structure with no symmetry element in $\mathbf{4}$ (Figure 6).

The last complex in the series, $\left[\left(\mathrm{UO}_{2}\right)_{8} \mathrm{~K}_{4}(\text { rac- } t-1,2-\mathrm{chdc})_{4}\left(\mathrm{C}_{2} \mathrm{O}_{4}\right)_{6}(18 \mathrm{C} 6)_{3}\left(\mathrm{H}_{2} \mathrm{O}\right)_{2}\right]$ (6), involves also the racemic form of $t-1,2-\operatorname{chdc}^{2-}$, and it has been synthesized under the same experimental conditions as complex $\mathbf{5}$, but it crystallized after a shorter reaction period, thus showing that subtle variations, for example in temperature (a factor which is not perfectly controlled with the setup used) can result in slightly different species being obtained in this complicated system, a reflection of the multiplicity of factors, both kinetic and thermodynamic, operative during the synthesis. The higher uranium:oxalate ratio in $\mathbf{6}$ could be due to the slow rate of oxalate generation. That the acidity of the reaction medium may diminish during the heating period is suggested by the absence of hydroxo ligands in $\mathbf{6}$ and their presence in $\mathbf{4}$ and $\mathbf{5}$. The asymmetric unit in $\mathbf{6}$ contains four uranyl cations, two $t-1,2-\mathrm{chdc}^{2-}$ and four oxalate ligands (two of them centrosymmetric), three centrosymmetric crown ethers, and two partly disordered potassium cations (see Supporting Information). Atoms U1 and U3 are chelated by two oxalate anions and bound to one donor from $t-1,2-\mathrm{chdc}^{2-}$, while atoms $\mathrm{U} 2$ and $\mathrm{U} 4$ are chelated by the two 
carboxylate groups of one $t-1,2-$ chdc $^{2-}$ ligand and by one oxalate, with a fifth donor from another $t-1,2-$ chdc $^{2-}$ ligand, as is now usual (Figure 7). Uranyl and carboxylate ligands form a 2D network
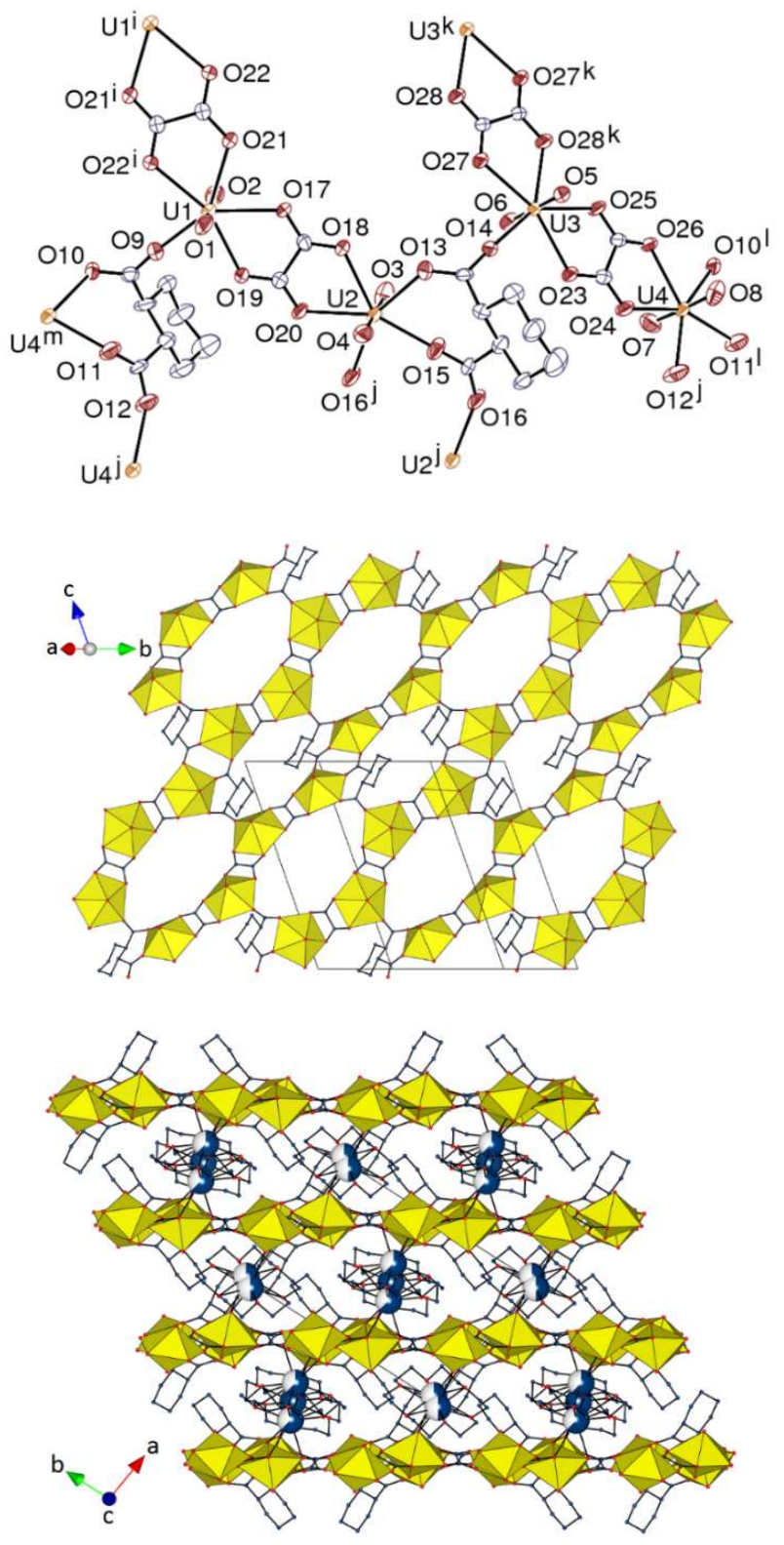

Figure 7. Top: View of compound 6, with K(18C6) groups omitted for clarity. Displacement ellipsoids are drawn at the $30 \%$ probability level. Symmetry codes: $\mathrm{i}=2-x, 1-y, 1-z ; \mathrm{j}=1-x, 2-y, 2-z ; \mathrm{k}=1-x, 2-y, 1-z ; 1=x-$ $1, y+1, z ; \mathrm{m}=x+1, y-1, z$. Middle: View of the uranyl-based 2D subunit. Bottom: View of the 3D framework with uranium polyhedra colored yellow and potassium atoms shown as blue spheres (parti-colored in the case of the disordered cations). Solvent molecules and hydrogen atoms are omitted in all views. 
parallel to $\left(\begin{array}{lll}1 & 1 & 0\end{array}\right)$ which has the same point symbol, $\{4.6 .8\}_{2}\left\{6.8^{2}\right\}$, as complex 2 (with $c-1,2-$ $\left.\operatorname{chdc}^{2-}\right)$. The uranyl dimers bridged by $t-1,2-\operatorname{chdc}^{2-}$ contain the two enantiomers of the ligand, as in complex 5. Here also, the potassium cations are affected by disorder. $\mathrm{K} 2$ and $\mathrm{K} 3$ are part of trans[K(18C6)(uranyl-O $\left.)_{2}\right]$ units (K2 being disordered over two positions related by inversion), with $\mathrm{K}-$ O(oxo) bond lengths of 2.751(12)-2.987(12) $\AA$. K1 is disordered over two positions, so that, with inversion symmetry, four badly resolved $\mathrm{K} 1$ positions are associated with the centrosymmetric 18C6. K1A is bound to all six donors of the crown, but it is displaced out of the crown plane due to interactions with one oxo and two carboxylate oxygen atoms located on the same side of the crown, in a manner remiciscent of that of $\mathrm{Na}(15 \mathrm{C} 5)^{+}$in complex 2 . The $\mathrm{K} 1 \mathrm{~A}-\mathrm{O}(\mathrm{oxo})$ bond length of 3.235(11) $\AA$ is larger than usual, and the K1A-O(carboxylate) bond lengths are 2.982(10) and 3.022(10) $\AA$; K1B is even more displaced from the crown plane and interacts with only two oxygen atoms from it, its coordination sphere being completed by two carboxylate [2.691(10) and 3.012(10) $\AA$ ] and two water [2.699(19) and 2.729 (19) $\AA$ ] ligands. As in complexes 3-5, the potassium ions link the planar uranyl carboxylate layers to form a 3D framework.

Luminescence properties. The emission spectra of compounds 1-5 in the solid state were recorded at room temperature under excitation at a wavelength of $420 \mathrm{~nm}$, a value suitable for excitation of the uranyl chromophore,${ }^{67}$ and they are shown in Figure 8; no sufficient amount of compound $\mathbf{6}$ in pure form was obtained for emission spectrum recording. In all emission spectra, the vibronic progression corresponding to the $S_{11} \rightarrow S_{00}$ and $S_{10} \rightarrow S_{0 v}(v=0-4)$ electronic transitions ${ }^{68}$ is well apparent, with four or five signals being prominent. The spectrum of 2 is particularly intense and well resolved, and the four main bands $\left[S_{10} \rightarrow S_{0 v}(v=0-3)\right]$, at 480, 500, 


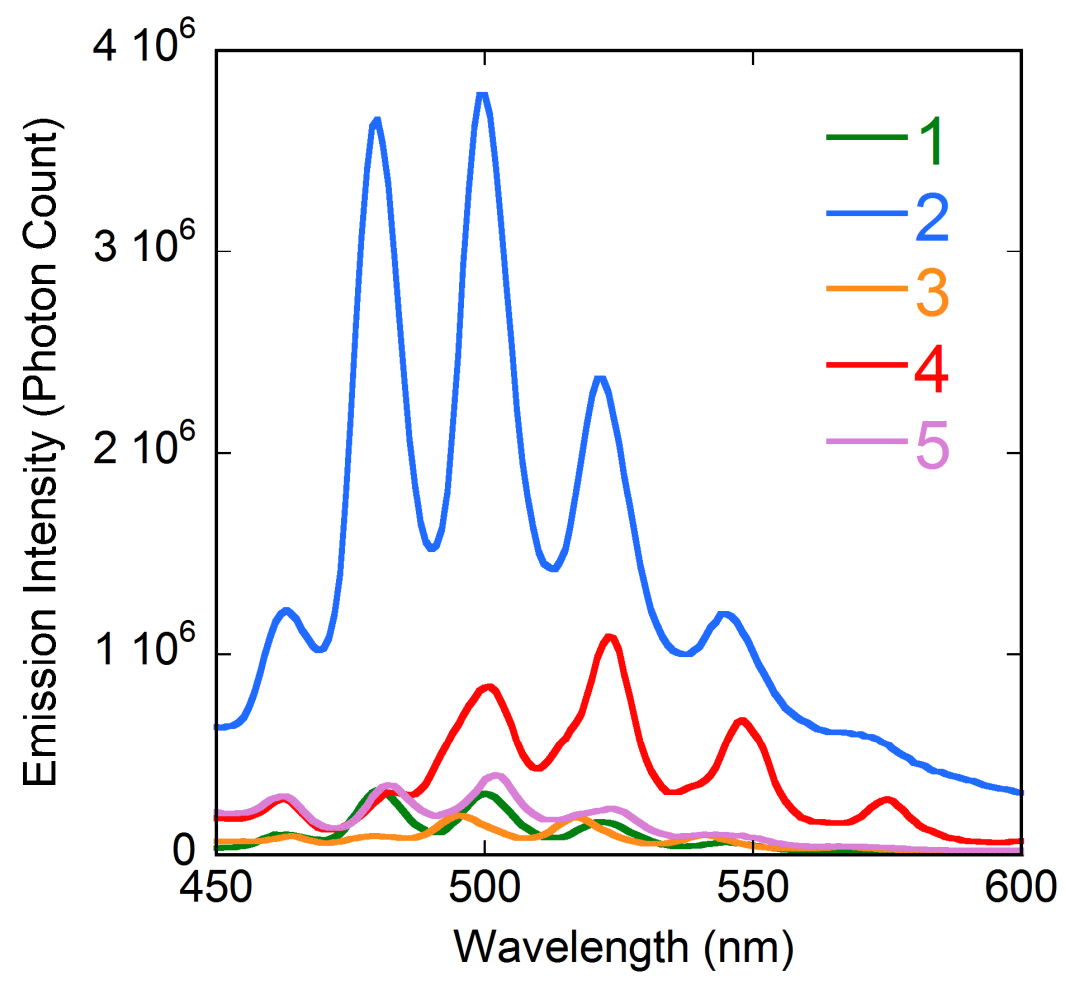

Figure 8. Emission spectra of compounds 1-5 in the solid state, under excitation at a wavelength of $420 \mathrm{~nm}$.

522 and $545 \mathrm{~nm}$, are blue-shifted with respect to usual values for uranyl ions with five equatorial carboxylate donors, being in the range typical of complexes with six equatorial carboxylate donors. ${ }^{24}$ The bands in the much less intense spectrum of $\mathbf{1}$ are at the same positions, which is less surprising since two of the three independent uranyl ions in it have six equatorial donors. Although weak, the spectrum of $\mathbf{5}$ is very close to that of $\mathbf{2}$, being red-shifted by $2 \mathrm{~nm}$ only. In contrast, the spectra of 3 and 4, with the three main signals at 495/501, 517/523 and 541/548 nm, respectively, are typical of complexes with five equatorial carboxylate donors. ${ }^{24}$ It is notable that the bands in the spectrum of $\mathbf{4}$ display clear evidence of additional shoulders, which may be unsurprising considering the number of inequivalent uranyl ions in this structure, but this is not observed in the other spectra. 


\section{CONCLUSIONS}

Although the present work concerns but a minor fraction of what would be possible were the full range of known crown ethers and all members of the alkali metal group to be investigated, it does justify the conclusion that crown ether complexes can be used to increase the dimensionality of uranyl ion coordination polymers. This is true only when the alkali metal cation is located at the centre of the quasi-planar crown, as shown by the case of $\mathrm{Na}(15 \mathrm{C} 5)^{+}$, for which the displacement of the cation with respect to the crown plane enables only additional coordination on one side, thus resulting in the group being merely decorating. In contrast, $\mathrm{K}(18 \mathrm{C} 6)^{+}$adopts most often a geometry suitable for trans-coordination to two additional donors. The propensity of alkali metal cations to bind to uranyl oxo groups, associated with the frequent formation of $2 \mathrm{D}$, nearly planar or gently undulating uranyl carboxylate subunits with oxo groups pointing outside, make for a perfect match between these essentially planar anionic and cationic moieties; indeed, in four of the presently described instances, linear $\mathrm{O}-[\mathrm{K}(18 \mathrm{C} 6)]-\mathrm{O}$ struts between layers of $2 \mathrm{D}$ uranyl coordination polymers. However, these $\mathrm{K}(18 \mathrm{C} 6)^{+}$links are not long enough to create cavities between the layers of a size greater than that required for the accommodation of water solvent molecules. Another drawback of these compounds is the frequent presence of extensive disorder, partially resolved at best, affecting the alkali cations and crown ethers.

Although not initially envisaged as part of the present work, the generation of oxalate under the reaction conditions used has proven to be a useful method of obtaining mixed-ligand uranyl coordination polymers, but it is notable that the deliberate addition of oxalic acid to (solvo)hydrothermal reaction mixtures often results in the formation of simple uranyl oxalate complexes, thus suggesting that the slow generation of oxalate when formed in situ is possibly a favourable factor. 
All the present complexes show uranyl ion emission with the characteristic resolution of vibronic fine structure. Although all complexes but one contain solely uranium ions in pentagonal bipyramidal environments, the emission maxima positions span a range wider than usually observed with similar carboxylate ligands. The case of complex $\mathbf{1}$ is of particular interest in that both pentagonal and hexagonal bipyramidal uranium centres are present but the emission spectrum is close to that typical of a purely hexagonal bipyramidal, tris-chelated species, indicating that emission from the pentagonal bipyramidal centres may be largely absent in this case, though this remains to be established by more sophisticated spectroscopic measurements.

\section{ASSOCIATED CONTENT}

\section{Accession Codes}

CCDC 1824390-1824395 contain the supplementary crystallographic data for this paper. These data can be obtained free of charge via www.ccdc.cam.ac.uk/data_request/cif, or by emailing data_request@ccdc.cam.ac.uk, or by contacting The Cambridge Crystallographic Data Centre, 12 Union Road, Cambridge CB2 1EZ, UK; fax: +44 1223336033.

\section{Supporting Information}

Experimental details. This information is available free of charge via the Internet at http://pubs.acs.org/.

\section{AUTHOR INFORMATION}

\section{Corresponding Authors}

*E-mail: pierre.thuery@cea.fr. (P.T.)

*E-mail: harrowfield@unistra.fr. (J.H.) 


\section{ORCID}

Pierre Thuéry: 0000-0003-1683-570X

Youssef Atoini: 0000-0003-4851-3713

Jack Harrowfield: 0000-0003-4005-740X

\section{Notes}

The authors declare no competing financial interest.

\section{REFERENCES}

1. Wang, K. X.; Chen, J. S. Extended Structures and Physicochemical Properties of Uranyl-Organic Compounds. Acc. Chem. Res. 2011, 44, 531-540.

2. Andrews, M. B.; Cahill, C. L. Uranyl Bearing Hybrid Materials: Synthesis, Speciation, and SolidState Structures. Chem. Rev. 2013, 113, 1121-1136.

3. Loiseau, T.; Mihalcea, I.; Henry, N.; Volkringer, C. The Crystal Chemistry of Uranium Carboxylates. Coord. Chem. Rev. 2014, 266-267, 69-109.

4. Su, J.; Chen, J. S. MOFs of Uranium and the Actinides. Struct. Bond. 2015, 163, 265-296.

5. Thuéry, P.; Harrowfield, J. Recent Advances in Structural Studies of Heterometallic UranylContaining Coordination Polymers and Polynuclear Closed Species. Dalton Trans. 2017, 46, $13660-13667$.

6. Poonia, N. S.; Bajaj, A. V. Coordination Chemistry of Alkali and Alkaline Earth Cations. Chem. Rev. 1979, 79, 389-445.

7. Gokel, G. W. Crown Ethers and Cryptands. Monographs in Supramolecular Chemistry No. 3, Stoddart, J. F., Ed.; RSC: Cambridge, 1991. 
8. Truter, M. R. Structures of Organic Complexes with Alkali Metal Ions. Struct. Bonding (Berlin) 1973, 16, 71-111.

9. Döbler, M. In Comprehensive Supramolecular Chemistry; Atwood, J. A., Davies, J. E. D., MacNicol, D. D., Vögtle, F., Eds.; Pergamon Press, Elsevier Science: Oxford, 1996; Vol. 1, (Gokel, G. W., Volume Editor), pp 267-313.

10. Steed, J. W. First- and Second-Sphere Coordination Chemistry of Alkali Metal Crown Ether Complexes. Coord. Chem. Rev. 2001, 215, 171-221.

11. Groom, C. R.; Bruno, I. J.; Lightfoot, M. P.; Ward, S. C. The Cambridge Structural Database. Acta Crystallogr., Sect. B 2016, 72, 171-179.

12. Rogers, R. D.; Bond, A. H.; Hipple, W. G.; Rollins, A. N.; Henry, R. F. Synthesis and Structural Elucidation of Novel Uranyl-Crown Ether Compounds Isolated from Nitric, Hydrochloric, Sulfuric, and Acetic Acids. Inorg. Chem. 1991, 30, 2671-2679.

13. Danis, J. A.; Hawkins, H. T.; Scott, B. L.; Runde, W. H.; Scheetz, B. E.; Eichhorn, B. W. X-Ray Structure Determination of Two Related Uranyl Phosphate Crown Ether Compounds. Polyhedron 2000, 19, 1551-1557.

14. Alekseev, E. V.; Krivovichev, S. V.; Depmeier, W. A Crown Ether as Template for Microporous and Nanostructured Uranium Compounds. Angew. Chem. Int. Ed. 2008, 47, 549-551.

15. Thuéry, P. Two Novel Uranyl-Organic Frameworks with Cyclohexane-1,3-Dicarboxylate Ligands. CrystEngComm 2009, 11, 232-234.

16. Adelani, P. O.; Albrecht-Schmitt, T. E. Synthesis of Uranyl Diphosphonate Compounds Using Encapsulated Cations as Structure Directing Agents. Cryst. Growth Des. 2011, 11, 4227-4237.

17. Gurzhiy, V. V.; Tyumentseva, O. S.; Krivovichev, S. V.; Tananaev, I. G. Novel Type of Molecular Connectivity in One-Dimensional Uranyl Compounds: [K@(18-crown- 
6) $\left.\left(\mathrm{H}_{2} \mathrm{O}\right)\right]\left[\left(\mathrm{UO}_{2}\right)\left(\mathrm{SeO}_{4}\right)\left(\mathrm{NO}_{3}\right)\right]$, a New Potassium Uranyl Selenate with 18-crown-6 Ether. Inorg. Chem. Commun. 2014, 45, 93-96.

18. Siidra, O. I.; Nazarchuk, E. V.; Sysoeva, E. V.; Kayukov, R. A.; Depmeier, W. Isolated Uranyl Chromate and Polychromate Units in Crown Ether Templated Compounds. Eur. J. Inorg. Chem. 2014, 5495-5498.

19. Gurzhiy, V. V.; Tyumentseva, O. S.; Krivovichev, S. V.; Tananaev, I. G. Hybrid One-Dimensional 15-Crown-5-ether-uranyl-selenate Polymers in $\left[\mathrm{K} @\left(\mathrm{C}_{10} \mathrm{H}_{20} \mathrm{O}_{5}\right)\right]\left[\left(\mathrm{UO}_{2}\right)\left(\mathrm{SeO}_{4}\right)\left(\mathrm{HSeO}_{4}\right)\left(\mathrm{H}_{2} \mathrm{O}\right)\right]$ : Synthesis and Characterization. Z. Anorg. Allg. Chem. 2015, 641, 1110-1113.

20. Gurzhiy, V. V.; Tyumentseva, O. S.; Tyshchenko, D. V.; Krivovichev, S. V.; Tananaev, I. G. Crown-Ether-Templated Uranyl Selenates: Novel Family of Mixed Organic-Inorganic Actinide Compounds. Mendeleev Commun. 2016, 26, 309-311.

21. Mäkelä, T.; Minkkinen, M. E.; Rissanen, K. Ion Pair Binding in the Solid-State with Ditopic Crown Ether Uranyl Salophen Receptors. Inorg. Chem. 2016, 55, 1339-1346.

22. Thuéry, P.; Harrowfield, J. Coordination Polymers and Cage-Containing Frameworks in Uranyl Ion Complexes with rac- and $(1 R, 2 R)$-trans-1,2-Cyclohexanedicarboxylates: Consequences of Chirality. Inorg. Chem. 2017, 56, 1455-1469.

23. Thuéry, P.; Harrowfield, J. Tetrahedral and Cuboidal Clusters in Complexes of Uranyl and Alkali or Alkaline-Earth Metal Ions with rac- and $(1 R, 2 R)$-trans-1,2-Cyclohexanedicarboxylate. Cryst. Growth Des. 2017, 17, 2881-2892.

24. Thuéry, P.; Harrowfield, J. Structural Consequences of 1,4-Cyclohexanedicarboxylate Cis/Trans Isomerism in Uranyl Ion Complexes: From Molecular Species to 2D and 3D Entangled Nets. Inorg. Chem. 2017, 56, 13464-13481. 
25. Kimura, K.; Watanabe, Y.; Suda, T.; Senda, H.; Hosoi, S.; Ohta, T.; Kunimoto, K. K. Crystal Structure of $(1 R, 2 R)$-trans-1,2-Cyclohexanedicarboxylic Acid- $(R)-1$-Phenylethylamine Salt. Anal. Sci. 1999, 15, 609-610.

26. Hooft, R. W. W. COLLECT, Nonius BV: Delft, The Netherlands, 1998.

27. Otwinowski, Z.; Minor, W. Processing of X-Ray Diffraction Data Collected in Oscillation Mode. Methods Enzymol. 1997, 276, 307-326.

28. Sheldrick, G. M. SHELXT - Integrated Space-Group and Crystal-Structure Determination. Acta Crystallogr., Sect. A 2015, 71, 3-8.

29. Sheldrick, G. M. Crystal Structure Refinement with SHELXL. Acta Crystallogr., Sect. C 2015, $71,3-8$.

30. Farrugia, L. J. WinGX and ORTEP for Windows: an Update. J. Appl. Crystallogr. 2012, 45, 849854.

31. Momma, K.; Izumi, F. VESTA: a Three-Dimensional Visualization System for Electronic and Structural Analysis. J. Appl. Crystallogr. 2008, 41, 653-658.

32. Blatov, V. A. TOPOS, Samara State University, Russia, 2004.

33. Demazeau, G. Solvothermal Reactions: an Original Route for the Synthesis of Novel Materials. $J$. Mater. Sci. 2008, 43, 2104-2114.

34. Thuéry, P.; Harrowfield, J. Modulation of the Structure and Properties of Uranyl Ion Coordination Polymers Derived from 1,3,5-Benzenetriacetate by Incorporation of $\mathrm{Ag}(\mathrm{I})$ or $\mathrm{Pb}(\mathrm{II})$. Inorg. Chem. 2016, 55, 6799-6816 and references therein.

35. Thuéry, P.; Harrowfield, J. Structural Variations in the Uranyl/4,4'-Biphenyldicarboxylate System. Rare Examples of 2D $\rightarrow$ 3D Polycatenated Uranyl-Organic Networks. Inorg. Chem. 2015, $54,8093-8102$ and references therein. 
36. Andrews, M. B.; Cahill, C. L. In Situ Oxalate Formation During Hydrothermal Synthesis of Uranyl Hybrid Materials. CrystEngComm 2011, 13, 7068-7078.

37. Knope, K. E.; Kimura, H.; Yasaka, Y.; Nakahara, M.; Andrews, M. B.; Cahill, C. L. Investigation of in Situ Oxalate Formation from 2,3-Pyrazinedicarboxylate under Hydrothermal Conditions Using Nuclear Magnetic Resonance Spectroscopy. Inorg. Chem. 2012, 51, 3883-3890.

38. Pedersen, C. J. Cyclic Polyethers and Their Complexes with Metal Salts. J. Am. Chem. Soc. 1967, 89, 7017-7036.

39. Bîrzescu, M.; Milea, M.; Roşu, D.; Ledeţi, I.; Rafailă, M.; Sasca, V.; Niculescu, M. Synthesis and Thermal Analysis of the Nickel(II) Oxalate Obtained Through the Reaction of Ethylene Glycol with $\mathrm{Ni}\left(\mathrm{NO}_{3}\right)_{2} \cdot 6 \mathrm{H}_{2} \mathrm{O}$. Rev. Roum. Chim. 2014, 59, 555-563 and references therein.

40. Gambardella, R. L.; Richardson, K. E. The Formation of Oxalate from Hydroxypyruvate, Serine, Glycolate and Glyoxylate in the Rat. Biochim. Biophys. Acta 1978, 544, 315-328.

41. Bombieri, G.; De Paoli, G.; Immirzi, A. Crown Ether Complexes of Actinide Elements. An XRay Study of the Conformational Change of the Crown Ether Within the $\mathrm{UO}_{2}\left(\mathrm{NO}_{3}\right)_{2}\left(\mathrm{H}_{2} \mathrm{O}\right)_{2}(18-$ crown-6) Molecule. J. Inorg. Nucl. Chem. 1978, 40, 799-802.

42. Thuéry, P.; Keller, N.; Lance, M.; Vigner, J. D.; Nierlich, M. Structural Investigation of Uranyl Complexes with Crown-Ethers, Azacrowns and Calixarenes. Structure of an Uranyl-Calixarene Bimetallic Inclusion Complex. New J. Chem. 1995, 19, 619-625.

43. Gong, Y.; Gibson, J. K. Crown Ether Complexes of Uranyl, Neptunyl, and Plutonyl: Hydration Differentiates Inclusion versus Outer Coordination. Inorg. Chem. 2014, 53, 5839-5844.

44. Spackman, M. A.; Jayatilaka, D. Hirshfeld Surface Analysis. CrystEngComm 2009, 11, 19-32.

45. Wolff, S. K.; Grimwood, D. J.; McKinnon, J. J.; Turner, M. J.; Jayatilaka, D.; Spackman, M. A. CrystalExplorer, University of Western Australia, 2012. 
46. Chapelet-Arab, B.; Nowogrocki, G.; Abraham, F.; Grandjean, S. Crystal Structure of New Uranyl Oxalates $\left(\mathrm{NH}_{4}\right)_{2}\left[\mathrm{UO}_{2}\left(\mathrm{C}_{2} \mathrm{O}_{4}\right)_{2} \cdot \mathrm{H}_{2} \mathrm{O}\right] \cdot 2 \mathrm{H}_{2} \mathrm{O}$ and $\left(\mathrm{NH}_{4}\right)_{2-x}\left(\mathrm{~N}_{2} \mathrm{H}_{5}\right)_{x}\left[\left(\mathrm{UO}_{2}\right)_{2}\left(\mathrm{C}_{2} \mathrm{O}_{4}\right)_{3}\right] \cdot 3 \mathrm{H}_{2} \mathrm{O}(x=0$ and $x$ =1). Comparison with other uranyl oxalates. Radiochim. Acta 2005, 93, 279-285.

47. Gjikaj, M.; Adam; A. Complexation of Alkali Triflates by Crown Ethers: Synthesis and Crystal Structure of $\quad\left[\mathrm{Na}(12 \text {-crown-4) })_{2}\right]\left[\mathrm{SO}_{3} \mathrm{CF}_{3}\right], \quad\left[\mathrm{Na}(15\right.$-crown-5) $]\left[\mathrm{SO}_{3} \mathrm{CF}_{3}\right], \quad[\mathrm{Rb}(18$-crown6) $]\left[\mathrm{SO}_{3} \mathrm{CF}_{3}\right]$, and $\left[\mathrm{Cs}\left(18-\right.\right.$ crown-6)][SO$\left.{ }_{3} \mathrm{CF}_{3}\right]$. Z. Anorg. Allg. Chem. 2006, 632, 2475-2480.

48. Danis, J. A.; Lin, M. R.; Scott, B. L.; Eichhorn, B. W.; Runde, W. H. Coordination Trends in Alkali Metal Crown Ether Uranyl Halide Complexes: The Series $[\mathrm{A}(\mathrm{Crown})]_{2}\left[\mathrm{UO}_{2} \mathrm{X}_{4}\right]$ Where A $=\mathrm{Li}, \mathrm{Na}, \mathrm{K}$ and $\mathrm{X}=\mathrm{Cl}$, Br. Inorg. Chem. 2001, 40, 3389-3394.

49. Thuéry, P.; Masci, B. Synthesis and Crystal Structure of 1:2 Mixed Uranyl/Alkali Metal Ions ( $\mathrm{Li}^{+}$, $\mathrm{Na}^{+}, \mathrm{K}^{+}, \mathrm{Cs}^{+}$) Complexes of $p$-tert-Butyltetrahomodioxacalix[4]arene. Dalton Trans. 2003, 24112417.

50. Thuéry, P. Uranyl Ion Complexation by Citric and Tricarballylic Acids: Hydrothermal Synthesis and Structure of Two- and Three-Dimensional Uranium-Organic Frameworks. Chem. Commun. 2006, 853-855.

51. Thuéry, P. Reaction of Uranyl Nitrate with Carboxylic Diacids under Hydrothermal Conditions. Crystal Structure of Complexes with L(+)-Tartaric and Oxalic Acids. Polyhedron 2007, 26, 101106.

52. Alsobrook, A. N.; Zhan, W.; Albrecht-Schmitt, T. E. Use of Bifunctional Phosphonates for the Preparation of Heterobimetallic 5f-3d Systems. Inorg. Chem. 2008, 47, 5177-5183.

53. Severance, R. C.; Cortese, A. J.; Smith, M. D.; zur Loye, H. C. Hydrothermal Synthesis, Structure, and Luminescence of a U(VI) Complex. J. Chem. Crystallogr. 2013, 43,171-177. 
54. Thangavelu, S. G.; Butcher, R. J.; Cahill, C. L. Role of N-Donor Sterics on the Coordination Environment and Dimensionality of Uranyl Thiophenedicarboxylate Coordination Polymers. Cryst. Growth Des. 2015, 15, 3481-3492.

55. Zhang, W.; Zhao, J. A Uranium-Potassium-Organic Framework Solids: Hydrothermal Synthesis, Structure, and Property of $\mathrm{K}\left[\left(\mathrm{UO}_{2}\right)_{3}\left(\mu_{3}-\mathrm{OH}\right)_{3}\left(\mu_{2}-\mathrm{OH}\right)\left(\mathrm{C}_{7} \mathrm{H}_{4} \mathrm{O}_{4} \mathrm{~N}\right)_{2}\right] \mathrm{OH}$. Inorg. Chem. Commun. 2006, 9, 397-399.

56. Giesting, P. A.; Porter, N. J.; Burns, P. C. A Series of Sheet-Structured Alkali Metal Uranyl Oxalate Hydrates: Structures and IR Spectra. Z. Kristallogr. 2006, 221, 589-599.

57. Masci, B.; Thuéry, P. Versatility of $\left\{\mathrm{M}(30\right.$-crown-10) $\}\left(\mathrm{M}=\mathrm{K}^{+}, \mathrm{Ba}^{2+}\right)$ as a guest in $\mathrm{UO}_{2}{ }^{2+}$ complexes of [3.1.3.1]- and [3.3.3]homooxacalixarenes. CrystEngComm 2007, 9, 582-590.

58. Thuéry, P.; Masci, B.; Takimoto, M.; Yamato, T. Supramolecular Assemblages from Uranyl Complexes of Calixarenes and Potassium Complexes of 18-Crown-6 or Dibenzo-18-crown-6. Inorg. Chem. Commun. 2007, 10, 795-799.

59. Masci, B.; Thuéry, P. Pyrazinetetracarboxylic Acid as an Assembler Ligand in Uranyl-Organic Frameworks. Cryst. Growth Des. 2008, 8, 1689-1696.

60. Thuéry, P. Uranyl-Alkali Metal Ion Heterometallic Complexes with Cucurbit[6]uril and a Sulfonated Catechol. Cryst. Growth Des. 2011, 11, 3282-3294.

61. Diwu, J.; Albrecht-Schmitt, T. E. Chiral Uranium Phosphonates Constructed from Achiral Units with Three-Dimensional Frameworks. Chem. Commun. 2012, 48, 3827-3829.

62. Unruh, D. K.; Gojdas, K.; Flores, E.; Libo, A.; Forbes, T. Z. Synthesis and Structural Characterization of Hydrolysis Products within the Uranyl Iminodiacetate and Malate Systems. Inorg. Chem. 2013, 52, 10191-10198. 
63. Lewis, A. J.; Yin, H.; Carroll, P. J.; Schelter, E. J. Uranyl-Oxo Coordination Directed by NonCovalent Interactions. Dalton Trans. 2014, 43, 10844-10851.

64. Novikov, S. A.; Grigoriev, M. S.; Serezhkina, L. B.; Serezhkin, V. N. Potassium and Magnesium Succinatouranilates - Synthesis and Crystal Structure. J. Solid State Chem. 2017, 248, 178-182.

65. Liebing, P.; Zaeni, A.; Olbrich, F.; Edelmann, F. T. Crystal Structures of Two Solvates of (18crown-6)-Potassium Acetate. Acta Crystallogr., Sect. E 2016, 72, 1757-1761.

66. Belghith, Y.; Toumi, H.; Daran, J. C.; Nasri, H. A One-Dimensional Polymeric Cobalt(III)Potassium Complex with 18-Crown-6, Cyanide and Porphyrinate Ligands. Acta Crystallogr., Sect. E 2014, 70, m104-m105.

67. Knope, K. E.; de Lill, D. T.; Rowland, C. E.; Cantos, P. M.; de Bettencourt-Dias, A.; Cahill, C. L. Uranyl Sensitization of Samarium(III) Luminescence in a Two-Dimensional Coordination Polymer. Inorg. Chem. 2012, 51, 201-206.

68. Brachmann, A.; Geipel, G.; Bernhard, G.; Nitsche, H. Study of Uranyl(VI) Malonate Complexation by Time Resolved Laser-Induced Fluorescence Spectroscopy (TRLFS). Radiochim. Acta 2002, 90, 147-153. 


\section{For Table of Contents Use Only}

\section{Crown Ethers and their Alkali Metal Ion Complexes as Assembler Groups in Uranyl-Organic Coordination Polymers with cis-1,3-, cis-1,2- and trans-1,2-Cyclohexanedicarboxylates}

Pierre Thuéry, Youssef Atoini and Jack Harrowfield

The propensity of alkali metal cations to be bound to uranyl oxo groups makes $\mathrm{K}(18 \text {-crown- } 6)^{+}$ an ideal link between uranyl-carboxylate layers with oxo groups protruding on both sides, thus generating three-dimensional frameworks. In contrast, the non-planar $\mathrm{Na}\left(15\right.$-crown-5) ${ }^{+}$cation is involved in additional coordination on one side only and is attached to the layers as a decorating group.

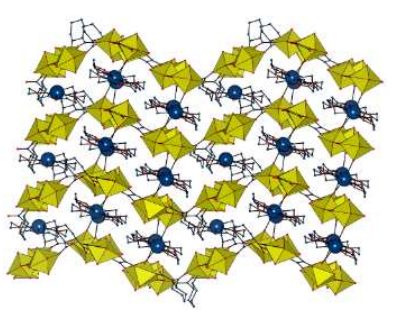

